\title{
Cold Stress in Citrus: A Molecular, Physiological and Biochemical Perspective
}

\author{
Amparo Primo-Capella *, Mary-Rus Martínez-Cuenca (D) and María Ángeles Forner-Giner
}

Centro de Citricultura y Producción Vegetal, Instituto Valenciano de Investigaciones Agrarias (IVIA), CV-315, km. 10, Moncada, 46113 Valencia, Spain; martinez_mru@gva.es (M.-R.M.-C.); forner_margin@gva.es (M.Á.F.-G.)

* Correspondence: primo_amp@gva.es; Tel.: +34-96-342-41-05; Fax: +34-96-342-40-01

\begin{abstract}
Due to climate change, we are forced to face new abiotic stress challenges like cold and heat waves that currently result from global warming. Losses due to frost and low temperatures force us to better understand the physiological, hormonal, and molecular mechanisms of response to such stress to face losses, especially in tropical and subtropical crops like citrus fruit, which are well adapted to certain weather conditions. Many of the responses to cold stress that are found are also conserved in citrus. Hence, this review also intends to show the latest work on citrus. In addition to basic research, there is a great need to employ and cultivate new citrus rootstocks to better adapt to environmental conditions.
\end{abstract}

Keywords: citriculture; citrus; rootstock; cold stress

Citation: Primo-Capella, A.;

Martínez-Cuenca, M.-R.;

Forner-Giner, M.Á. Cold Stress in

Citrus: A Molecular, Physiological and Biochemical Perspective.

Horticulturae 2021, 7, 340. https://

doi.org/10.3390/horticulturae7100340

Academic Editor: Sergio

Ruffo Roberto

Received: 3 August 2021

Accepted: 18 September 2021

Published: 24 September 2021

Publisher's Note: MDPI stays neutral with regard to jurisdictional claims in published maps and institutional affiliations.

Copyright: (C) 2021 by the authors. Licensee MDPI, Basel, Switzerland. This article is an open access article distributed under the terms and conditions of the Creative Commons Attribution (CC BY) license (https:/ / creativecommons.org/licenses/by/ $4.0 /)$.

\section{Introduction \\ 1.1. Abiotic Stress}

Climate change is bringing about changes in the weather that cause severe droughts, cold waves, and waterlogging due to excess rainfall, among others. It may seem paradoxical with climate change and global warming to think that cold waves may be caused by the greenhouse effect. Currently, there are many theories on its origin, but the fact is that increasingly extreme changes occur within seasons in relation to water regimes, such as heavy rains after extreme drought periods, or with thermal imbalances, such as winters with an average temperature that is $1-2{ }^{\circ} \mathrm{C}$ higher than all-time records, followed by waves of extreme cold [1-4]. Hence the importance of new improvement programs to obtain new crops that are more tolerant to abiotic stresses. Plant breeding programs against abiotic stress are very complex as they involve many genes. To carry them out, first it is necessary to know the crop of interest very well, how the studied stress affects it and what mechanisms of action the plant uses to survive it.

\subsection{Citriculture and Cold Stress}

On a global scale, citrus is one of the fruit culture sectors with the highest production, which exceeded 123 million tons in 2016 (FAOSTAT, October 2019). The citrus market is generally divided into the production of oranges, mandarins (tangerine, mandarin, clementine, satsuma), lemons, and limes. In 2018, the largest producers in the world were Brazil and China with 17 and 10 million tons of oranges, respectively. Spain is in the top 10 world producers (FAOSTAT, October 2019) with a total production of 4 million tons of oranges in 2018. Spain especially stands out for its mandarin production with 2 million tons, is in second place behind China (19 million tons) and is also the world's leading exporter for exporting more than $50 \%$ of its production.

The grafting technique in agriculture has become an essential technique for the survival and cultivation of certain annual and arboreal species. This technique, which combines the aerial part and roots of two different species, allows farmers to improve crops against various problems that can arise, such as the distinct biotic and abiotic stresses 
present in the growing medium, low productivity at harvest, or simply due to a change in the harvest season to achieve more competitive prices for its harvest.

Grafting generally affects three important plant processes, namely: the use and transport of water and nutrients, the production and transport of hormones, and the large-scale movement of proteins, mRNAs and sRNAs [5]. The rootstock/variety combination results in transmissibility by the rootstock of different qualities that are considered beneficial for the variety. For example, it is known that Poncirus trifoliata is one of more tolerant rootstocks to tristeza virus (CTV) which, when grafted with a CTV-sensitive variety, is capable of transmitting tolerance capacity [6,7]. In other words, rootstocks must be able to transmit a quality desired by farmers to a variety and, depending on the selected rootstock/variety combination, these skills will differ [8-11].

These graft-induced benefits are easy to demonstrate from a physiological point of view, but it is important to give an answer to what happens at the molecular level and be able to offer an integrated view of the long-distance communication between the rootstock and variety. Thanks to certain techniques like RNA sequencing, it was demonstrated that many transcripts are capable of translocating between the rootstock and variety, which gives rise to the communication and long-distance control of different characters [12-14]. Knowledge of the transmissibility of the genomes between both plants allows us to understand and address the problems faced today.

Low-temperature stress is one of the abiotic stresses that leads to most losses in citrus. In December 1990, the losses in California were quantified at 500 million dollars in fresh fruit, and approximately 450,000 ha of affected trees [15]. In Valencia, Spain, cold losses were also very marked in citriculture history. In 2010, two consecutive frosts caused losses of 142 million euros according to AVA-Asaja (Valencian Association of Farmers) Records.

Citrus is considered a tropical and subtropical crop that is generally vulnerable to cold and freezing [16-18]. In Spain, the best-quality citrus fruits are obtained in areas with a temperature range that lies between $23^{\circ} \mathrm{C}$ and $34^{\circ} \mathrm{C}$ (with a minimum temperature of $13{ }^{\circ} \mathrm{C}$ and a maximum one of $39^{\circ} \mathrm{C}$, respectively) [19], with variations between species and varieties. If temperatures lie beyond this range, they may cause massive damage [17]. Citrus fruit are self-inductive crops (i.e., do not need any climatic circumstances to induce flowering) and do not depend on lowering temperatures to flourish [20]. However, flowering and, consequently, production, are markedly stimulated by environmental factors, including a regime of moderately low temperatures under subtropical conditions, and water stress under tropical conditions [21]. The threshold temperature that kills young shoots is $-12{ }^{\circ} \mathrm{C}$ [22], but some citrus fruit can tolerate a temperature of $-10^{\circ} \mathrm{C}$ [23] (Figure 1). This is the case of Poncirus trifoliata (L.) Raf., which is the most tolerant citrus rootstock to low temperatures [24-26]. Nevertheless, its sensitivity to iron chlorosis is currently in disuse in the Mediterranean region because soil there is extremely calcareous [11,27-29]. Instead, we find that the Carrizo rootstock [Citrus sinensis (L.) Osbeck. x Poncirus trifoliata (L.) Raf.] and Forner-Alcaide hybrids [28,30-34] are extensively used. Therefore, in addition to the interest that Poncirus trifoliata attracts for its resistance, we are also interested in other hybrids grown in the Mediterranean region. The lemon tree Citrus macrophylla is used as a rootstock for grafting with lemon trees because it is tolerant to the tristeza virus (CTV). This vigorous rootstock is characterized by its high sensitivity to low temperature $[18,24,35,36]$ and its sensitivity to CTV when it is grafted onto other varieties.

The influence of rootstocks on fruit quality-related traits has a proven significant effect on mandarin fruit size through cell size regulation [37], and also on tree growth, yield and quality, the leaf mineral composition of lemon [38], and even on the flavonoid content of lemon juice [39].

Some sweet oranges [(Citrus sinensis) L. Osbeck], such as Tarocco, Moro, and Sanguinello, are characterized by the presence of anthocyanins in both flavedo and pulp, and crops contain the highest flavonoids content in fruit and vegetables [40]. It was shown that the content of these compounds depends on different factors that are both endogenous to the species (pigmented variety, maturation process, etc.) and external or environmental 
(exposure to light, nutritional balance, hormones, xenobiotics, and temperature [41]. For these reasons, this variety is very interesting to study low-temperature stress. Table 1 shows the sensitivity/tolerance to cold stress of the different citrus genotypes reported in Florida in Randall Driggers' group [24].

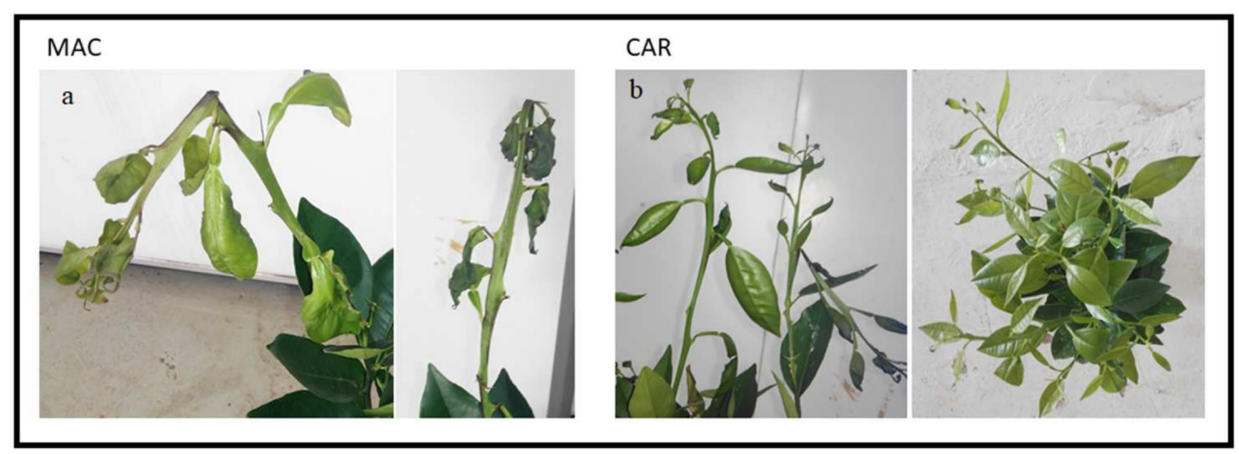

Figure 1. Damaged shoots of Citrus macrophylla (a) and Carrizo citrange (b) seedlings grafted with the Valencia delta seedless variety exposed to $0{ }^{\circ} \mathrm{C}$ for 30 days.

Table 1. Citrus cold-tolerant/-sensitive varieties to cold stress [24].

\begin{tabular}{ccc}
\hline Botanical Name & Common Name & Cold Tolerance \\
\hline Microcitrus inodora & Large leaf Australian wild lime & Sensitive \\
Citrus nobilis Lour. & King tangor & Sensitive \\
C. reticulata ('Clementine' $x$ 'Orlando') & Lee mandarin & Sensitive \\
Microcitrus australis & Australian round lime & Sensitive \\
C. reticulata Blanco & Parson's Special & Sensitive \\
C. sunki hort. ex Tan. & Sunki mandarin & Medium \\
C. volkameriana/C. limonia Osbeck & Volkamer lemon hybrid & Medium \\
C. jambhiri Lush. & Florida rough lemon & Medium \\
C. macrophylla Wester & Alemow & Medium \\
C. reticulata Blanco & Sun Chu Sha mandarin & Medium \\
C. sinensis Osbeck & Pineaple sweet orange & Tolerant \\
C. aurantium L. & Standard sour orange & Tolerant \\
Glycosmis penthaphylla & Orange berry & Tolerant \\
C. paradisi 'Duncan' $\times$ P. trifoliata) & Swingle citrumelo & Tolerant \\
Poncirus trifoliata & Citrus trifoliate & Tolerant \\
\hline
\end{tabular}

Very few studies were carried out to compare grafted citrus under cold stress. A cold hardiness study conducted with a tetraploid Carrizo citrange rootstock showed enhanced natural chilling stress tolerance for common clementine [42]. Carrizo citrange is a widespread rootstock that resulted from crossing sweet orange (Citrus sinensis Osb.) and Poncirus trifoliata (L. Raf), which possesses a certain degree of the cold tolerance from the Poncirus trifoliata parental [43]. Other works with the commercial rootstock Carrizo grafted onto Valencia delta seedless were carried out by María Ángeles Forner and Javier Terol's groups to demonstrate the rootstock influence under cold stress [9,44]. The metabolomic and transcriptomic study performed by these groups indicates that the mechanisms activated in plants shortly after cold exposure remain active in the long term. Both hormone quantification and differential expression analyses suggest that ABA signaling might play a relevant role in promoting the cold hardiness or sensitiveness of Valencia sweet orange grafted onto Carrizo citrange or Citrus macrophylla rootstocks, respectively. This work provides new insights into the mechanisms by which rootstocks modulate resistance to abiotic stress in the production variety grafted onto them ([44] under review).

\section{Cold Stress}

Plants are exposed to an environment with its specific conditions and reach an optimal steady state in which their metabolism is optimized for this condition. This includes 
adjustments in the concentration and activity of enzymes, and also in the concentration of metabolites, which allow the metabolism to function as efficiently as possible under the conditions it is found. When plants are exposed to a changing environment, a wide range of responses can take place over time. The cellular changes in responses can be divided into three categories.

\subsection{Molecular Response at Low Temperature}

The molecular response at low temperature can occur in two ways:

1. Independent CBF activation pathway (C-repeat binding factors). That is given by the activation of the COR (cold-regulated) response genes from an independent pathway of the CBF transcription factors;

2. Dependent on the CBF-COR route. The CBF regulon is the central response to low temperature. It is an activation cascade that leads to the activation of the COR response genes that depend on the CBF transcription factors.

These COR response genes are rapidly induced from minutes to hours by low temperatures [45]. Many gene products are suggested to be COR genes and act in the acclimatization response and subsequent cold tolerance [46]. These genes include osmoprotector synthesis enzymes, LEA proteins, transcription factors, protein kinases, proteins associated with lipid metabolism, hormone response proteins, cell wall modifiers, and chloroplast proteins [46].

\subsubsection{Stress Response by the Dependent CBF Pathway}

Sequentially, as stress is detected by plants, membrane destabilization occurs and is the first cause of plant damage by freezing $[47,48]$. During the acclimatization process, the cryostability process of the plasma membrane increases because of the alteration to the composition of the lipids that alter its behavior when facing dehydration. Uemura's group demonstrated changes in lipid composition during low-temperature acclimatization $[49,50]$. They specifically observed, on the one hand, an increase in the proportion of phospholipids because of the rising proportion of the di-unsaturated species of phosphatidylcholine and phosphatidylethanolamine and, on the other hand, a smaller proportion of cerebroside lipids [50].

Plasma membrane destabilization leads to a higher concentration of cytosolic calcium [50,51]. Regulation in the proteins that act as calcium sensors is direct or occurs through a signaling cascade from kinases to induce the expression of the genes responsible for the activation of the cold response to pre-existing transcription factors [52-54]. The increase in calcium is transitory and exhibits a characteristic peak caused by a specific vacuolar calcium antiporter known as a calcium exchanger $\left(\mathrm{CAX} 1 \mathrm{Ca}^{2+} / \mathrm{H}^{+}\right)$[52] that leads plants to repeatedly react to the low-temperature signal. Thus the second phase activation of the response to cold begins, which prolongs in time in a third phase of response to cold, known as acclimatization [46]. The calcium influx reaches a receptor kinase regulated by calmodulin 1 and 2 (CRLK1 and CRLK2), and begins a signaling cascade of the specific cold pathway (Figure 2) $[55,56]$. This signaling begins with the activation of protein kinases (MPK) that compromise three protein kinases, MEKK, MKK and MPK, which consecutively act $[57,58]$. These MPKs can activate or repress the next transcription factor in the signaling pathway, ICE1 (inducing CBF expression 1), which is an MYC-like helix-turn-helix transcription factor that binds in CBF gene promoters [59-62]. These MPKs can activate or suppress upstream of ICE1. Thus, MKK $4 / 5$ and MKK3 $/ 6$ specifically promote ICE1 repression and, consequently, the repression of the response at low downstream temperatures $[56,63]$. On the contrary, ICE1 expression is induced by MEKK1, MKK1/2, and MPK4, which gives rise to the activation of the cold response pathway. In addition to regulation by MPKs, the stability and, therefore, ICE1 protein activity are also regulated by the posttranslational modification of sumoylation by SUMO E3 ligase SIZ1 $[62,64,65]$. Thus, ICE1 reaches the nucleus and activates the central transcription factors of the cold response: the CBF genes. This pathway of activation of the response genes plays an important role in tolerance to low temperature stress in not only Arabidopsis thaliana, but also in other tree 
species like poplar, birch, apple, and citrus $[25,66,67]$. The CBF genes are also known as DREBs (dehydration-responsive element-binding factors) and generally comprise three members, CBF1, CBF2, and CBF3 (also called DREB1b, DREB1c, and DREB1a, respectively), in Arabidopsis thaliana. However, this may vary depending on the species. For example, in poplar, the induction of four CBF genes (CBF1, CBF2, CBF3, CBF4) was seen in response to low temperatures [66]. Thus, CBFs activate low-temperature response genes, called COR, which act in both the second phase of the response (minutes-hours) and the acclimatization phase (days-weeks).

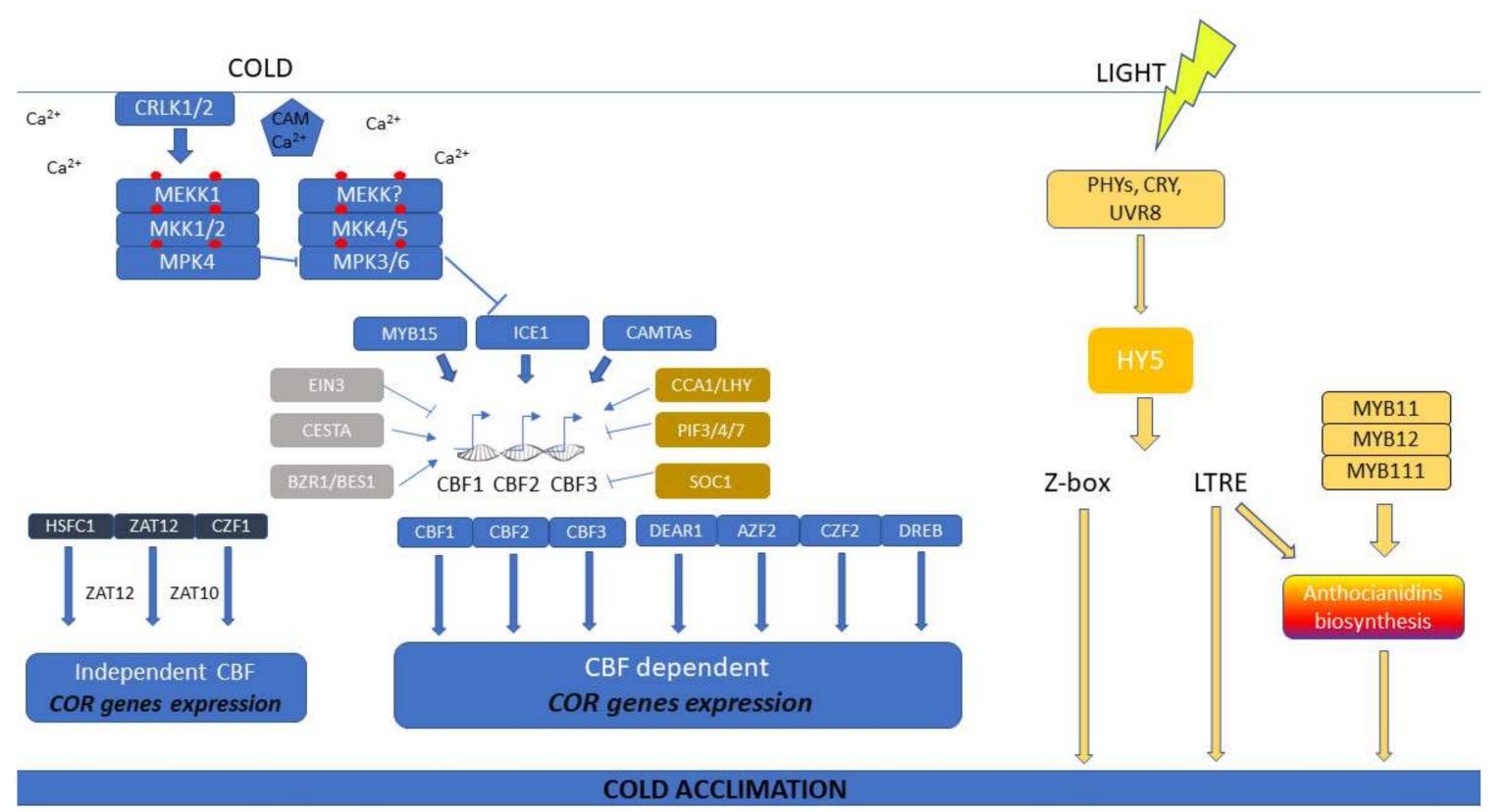

Figure 2. Representation of cold stress signaling, cold genes response, and acclimation.

In addition to ICE1, more activators and repressors of the CBF regulon are known to bind to its promoters and are induced in the presence of cold. MYB15 is an MYB-type transcription factor that can be activated in the presence of low temperatures and binds directly to the promoters of $\mathrm{CBF} 1, \mathrm{CBF} 2$, and CBF3 to bring about their repression [68]. Their expression is also thought to be regulated by MPKs signaling [69,70].

Another transcription factor that activates the expression of CBFs is calmodulin binding transcription activator (CAMTA) [71] (Figure 2). CAMTA 1, CAMTA 2, CAMTA 3, and CAMTA 5 induce CBFs. CAMTA 3 and CAMTA 5 act in the first minutes of temperatures lowering, and it seems to be related to sudden changes in temperature (day/night), and not to progressive changes in temperature which happens with seasonal changes [71,72].

Plants process and integrate the signals surrounding them related to seasonal changes and light. This is a crucial element for their response to acclimatization and tolerance to cold (Figure 2). Phytochromes (PHYA, PHYB, PHYC, PHYD and PHYE) absorb red and far-red light, while cryptochromes (CRY1, CRY2, and CRY3) absorb blue light and UV-A light [73]. Phytochromes are known to activate COR genes like COR15a and COR14b, and regulate the genes targeted by CBFs under near/far-red light conditions [74].

Phytochromes activate the bZIP long hypocotyl 5 (HY5) transcription factor, which happens to be a central modulator of the coordinated response between light signaling and plant development, and also regulates other genes through subnetworks using other regulators [75]. HY5 is overexpressed by low temperatures and mediates the induction of the genes expressed in the presence of this stress due to its binding to the Z-box of promoters, which constitute an LTRE (low-temperature response element) domain or other LTREs yet to be characterized [76]. 


\subsubsection{The Molecular Response in Citrus under Cold Stress}

The molecular response at low temperatures as indicated above is a general response that it is known in model plants, but previous experiments have found that this response its conserved in Citrus spp. [77,78].

In Citrus sinensis Osbeck cv. Gannanzao grafted onto the Poncirus trifoliata rootstock, CAMTA genes are conserved and intervened in abiotic stress regulation processes, such as cold, salt and drought, and also respond to ABA and JA treatments [3]. Specifically after cold stress treatment, a 3-fold induction of CsCAMTA1, CsCAMTA2, CsCAMTA3, CsCAMTA4, and to a lesser extent of CsCAMTA5, was observed at 24 and $48 \mathrm{~h}$ [79].

Another study in Poncirus trifoliata showed the conserved function of MAPK in a cDNA amplified fragment length polymorphism (cDNA-AFLP) assay. This group located a putative MAPK3 in Poncirus trifoliata and observed that its expression at $4{ }^{\circ} \mathrm{C}$ for $17 \mathrm{~h}$ was 17-fold vs. its control expression [80].

The inducer of CBF expression gene ICE1, as previously mentioned, has a complex regulation. ICE1 is a bHLH transcription factor and, in citrus, some groups are working to elucidate its function. Liu Jihong's group performed some works in Poncirus trifoliata and isolate a bHLB with a probable putative ICE1 function [81-83]. One of these articles shows that PtrbHLH overexpression of tobacco (Nicotiana tabacum) or lemon (Citrus limon) conferred enhanced tolerance to the cold with chilling or freezing temperatures, whereas the down-regulation of PtrbHLH in trifoliate orange by RNA interference (RNAi) resulted in marked cold sensitivity [81]. In a second study, the putative ICE1 from Poncirus trifoliata overexpressed in lemon and tobacco showed greater activity of antioxidant enzymes, such as superoxide dismutase and catalase, and were detected in transgenic lines under cold conditions. Taken together, these results demonstrate that PtrICE1 plays a positive role in cold tolerance, which may be due to the modulation of polyamine levels by interacting with the $A D C$ gene [82]. A third work in pummel was performed, in which the overexpression of transgenic lines accumulated dramatically lower reactive oxygen species (ROS) levels consistently with marked activity and high expression levels of antioxidant enzymes (genes), including catalase (CAT), peroxidase, and superoxide dismutase [83].

The putative HOS1 gene has been isolated from Poncirus trifoliata by Zhong-Hai Sun group in 2010 [84]. In their work, PtHOS1 was cloned, its protein was isolated and its gene expression was quantified in roots, stems, and leaves [84]. Interestingly, the PtrHOS1 expression underwent a declining period in leaves, stems, and roots after cold and ABA treatments, which suggests that the PtrHOS1 expression was down-regulated by both cold and ABA, which occurs in other species [84].

The CBF genes' function was demonstrated in two works in which CBF1 was isolated from citrus and cloned to demonstrate its function when faced with cold stress. The first one, putative CBF1, was isolated from Poncirus trifoliata (PtCBF1) and Citrus paradisi (CpCBF1) [78]. PtCBF1 accumulated not only earlier, but also at higher levels than CpCBF1. Furthermore, CORc115, a cold-induced group II LEA gene, also accumulated earlier and at higher levels in P. trifoliata in response to cold temperatures [78]. The second one was an isolated putative CBF1 from Poncirus trifotiala, sweet orange (Citrus sinensis), pummelo (Citrus grandis), and rough lemon (Citrus jambhiri) with complete open reading frames. The results of the multiple sequence alignment and phylogenetic analyses on putative protein sequences suggest that AP2 DNA binding domains and CBF signature sequences are highly conserved in four citrus CBF proteins [85].

The response to cold stress that takes place through light was also conserved in citrus, as demonstrated in two very recent works. One was carried out in pigmented oranges, in which the CgRuby1 promoter was isolated from Citrus grandis and overexpressed in Arabidopsis thaliana [86]. It was shown how transcription factor HY5 binds to the Ruby1 promoter to give rise to the synthesis of anthocyanins, and this response is also conserved in citrus [86]. Another very recent work about the response to light was carried out by Juan Xu's group, who found that the overexpression of Citrus sinensis CsPIF8 led to an increase 
in anthocyanin synthesis with low temperatures in transgenic tomato plants and grapefruit calli [87].

\subsection{Physiological Response}

Once signaling occurs, a series of physiological responses takes place in plants. A drop in temperature, without freezing, is harmful for plant tissues because the fluidity in membranes is lost due to the increasing proportion of unsaturated fatty acids that need to adapt to the new conditions.

Changes occur in the structure of chloroplast thylakoids, chlorophyll content, the activity of photosynthetic enzymes and electronic transport, which are associated with a drop in temperatures. However, the relation between physiological changes is not entirely clear [88]. These changes combined with stomatal closure are known to be largely responsible for declining photosynthesis in winter [89].

The result is ion leakage, which is caused by the inactivation of the channels and pumps anchored to the membrane [90], which affect any physiological process that takes place in the membrane that can be cellular and of any other organelle.

\subsubsection{Membrane Changes in Citrus under Cold Stress}

In citrus, changes in the structure of cell membranes and the composition of lipids was also shown as mentioned above. In many studies carried out at low temperatures, losses of ions and ruptures of the membrane occurred, thus damaging the processes taking place there [91-96].

In 1985, George Yelenosky's group analyzed the membrane and damage caused by cold stress in fatty acids. Three genotypes were compared: Citrus sinensis, Poncirus trifoliata and a hybrid between ((Citrus paradisi $\times$ Poncirus trifoliata) $\times$ Citrus sinensis). Fatty acids degradation was greater in phosphatidylcholine (89\%), phosphatidylglycerol (83\%), monogalactosyldiglyceride ( $79 \%$ ), and digalactosyldiglyceride (50\%). Total leaf fatty acids in the freeze-thaw regime increased $12 \%$ in the cold hardened hybrid. Three molecular species of triacylglycerol, which were rich in linolenic acid, increased in the hardened hybrid in the freeze-thaw regime [96]. The increase in highly unsaturated triacylglycerol species under freeze-thaw stress suggests that triacylglycerol plays a role in maintaining the fluidity of biomembranes under freezing conditions [96].

As with Citrus sinensis and Poncirus trifoliata, for grapefruit (Citrus paradisi) it was shown that the expression of the genes involved in both fatty acid biosynthesis and phospholipids degradation was strongly activated, whereas several fatty acid desaturases were down-regulated, except the acyl-[acyl-carrier-protein] desaturase and stearoyl-acyl carrier protein desaturase (Genbank CV706341 and CN182241CV706341CN182241), which were specifically up-regulated in the cold-acclimated fruit [97]. Likewise in blood orange or finger citron, the gene expression of some desaturases lowered [94,95].

\subsubsection{Photosynthesis and Cold}

Photosynthesis is known as one of the most temperature-sensitive physiological processes in plants. Therefore, understanding the physiological processes underlying the temperature response of photosynthesis and its acclimatization is important for both agriculture and the environment. Many plants are well able to adjust their photosynthetic characteristics to their growth needs depending on temperature [98-102].

Some of the mechanisms that lead to low-temperature acclimatization in winter annuals also do so at high irradiation [103-105]. Thus, the photosynthetic adjustment shown by cold-hardened plants resembles that exhibited by plants exposed to high light intensity, while the photosynthetic response of non-hardened plants is imitated by plants growing at low light intensity. The role of light in developing tolerance to freezing is also indicated by improved freezing tolerance under high light conditions with no cold treatment [106]. These results indicate that low temperature and light induce signaling pathways that overlap and accelerate others while plants develop cold tolerance. Several 
studies show that light can also substantially broaden the wide range of early protective compounds that are connected during the hardening process [107-109].

\section{Photoinhibition}

Photoinhibition is a phenomenon that reduces photosynthetic activity, mainly due to the assimilation of the $\mathrm{CO}_{2}$ induced by excess light [110]. Although reduced photo assimilation may depend on damage to some photosynthetic machinery components, the term inhibition is often used to define the inhibition of photosystem II (PSII) activity [111-113]. As light is the energy required to drive the photosynthesis process, photoinhibition is inevitable when light exceeds the photosynthetic rate. However, the extent of photoinhibition depends on the photodamage-PSII repair balance [114].

Photosystem II (PSII) is the most susceptible component that can be damaged in thylakoid membranes. The main result of abiotic stress is to make PSII prone to photoinhibition [112]. In fact, citrus leaves subjected to temperatures above $0{ }^{\circ} \mathrm{C}$ do not show any symptoms. However, when their photosystems are studied by the chlorophyll fluorescence imagine technique (CFI), damage to photosystem II is detected (Figure 3). This technique is very helpful for evaluating damage due to low temperatures. Photosystem I (PSI) is less frequently damaged thanks to the highly efficient photoprotection mechanism, with which it prevents photoinhibition [115]. PSI photoinhibition occurs when PSII's supply of electrons exceeds its ability to accept electrons [116]. When PSI is photodamaged, its recovery process is very long [117]. However, the photoinhibition mechanisms of PSI are not yet well understood.

\subsubsection{Photosynthesis and Photoinhibition in Citrus under Cold Stress}

In citrus, there are many examples shown in different citrus species that photosynthesis and photosystems are damaged in the presence of low temperatures: in Citrus junos [91], in Carrizo citrange [9,42], in Fortune mandarin and Ellendale tangor [118], in Citrus deliciosa and Poncirus trifoliata var. 'Pomeroy' [119], Citrus clementina [42], Citrus medica (fingered Citron) and sweet orange [120] and satsuma mandarin [121]. In all cases, photosynthesis $(\mathrm{Pn})$ decreases, stomatal closure takes place (Gs), respiration reduces and internal $\mathrm{CO}_{2}$ concentration $(\mathrm{Ci})$ rises. Therefore, photoinhibition occurs and stops the function of PSII to lower Fv/Fm values.

\subsection{Water Potential}

Water balance in plants is very important for physiological, cellular, and metabolic processes to be carried out. Water can be transported in a plant in three ways.

1. Apoplastic transport, which occurs along cell walls and without cell barriers, and gives rise to water transport over long distances that favors the water potential;

2. Transport by the simplastic route, which takes place between cells through plasmodesmata;

3. Transcellular transport through cell membranes. In the presence of abiotic stress like drought, salinity, or temperature stress, plants are compromised between water use to perform physiological $\mathrm{CO}_{2}$ fixation functions, water photolysis, and transpiration or stopping resources consumption to, thus, stop growth.

PIPs and Low-Temperature Stress

Transcellular water transport is carried out mainly by aquaporins. Aquaporins belong to a group of highly conserved membrane-binding proteins, better known as MIP (major intrinsic protein). Aquaporins are a large family of proteins, with 35 genes coding for aquaporins in Arabidopsis [122,123], 31 in maize [124], 33 in rice [125], 47 in tomato [126], 55 in poplar [127], 66 in soybean [128], 50 in banana [129], 71 in cotton [130], 41 in sorghum [131], and 34 in sweet orange from [132]. MIPs are classified according to their expression patterns, levels of modification in the amino acid sequence, regulation and intracellular location, which means they are classified into different families. PIPs (plasma membrane intrinsic proteins), NIPs (nodulin-26-like intrinsic proteins) and XIPs (uncategorized X intrinsic 
proteins) are generally located in the plasma membrane and are expressed on the cell surface, while TIPs (uncategorized X-proteins intrinsic properties of tonoplast) are located in the tonoplast membrane, which is the vacuole membrane [122]. However, some NIPs and SIPs (small basic intrinsic protein) are located in the endoplasmic reticulum [123].

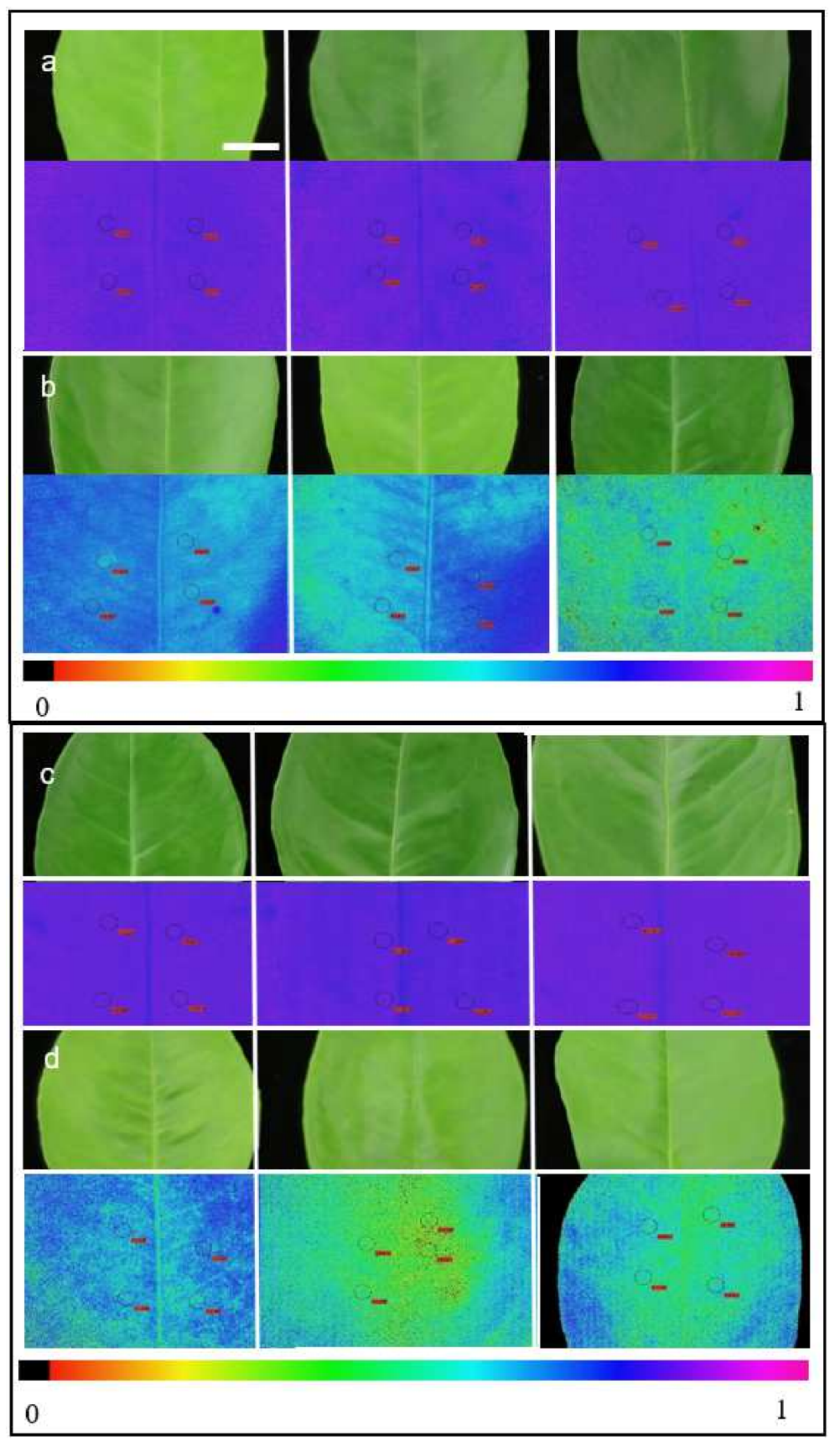

Figure 3. Representation of CFI (chlorophyll fluorescence imaging technique) of cold symptoms in citrus leaves exposed for 30 days to $1^{\circ} \mathrm{C}$. $(\mathbf{a}, \mathbf{c})$ are the control groups of Carrizo citrange rootstock and Citrus macrophylla rootstock, respectively, grafted with the Valencia delta seedless variety. $(\mathbf{b}, \mathbf{d})$ where the cold treatment group of the Carrizo citrange rootstock and the Citrus macrophylla rootstock, respectively, grafted with the Valencia delta seedless variety.

\subsection{Water Balance in Citrus under Cold Stress}

Water balance in citrus in the presence of low temperatures can be contradictory. Low temperatures lead to stomatal closure, decreased transpiration, and a drastically reduced osmotic potential $(\Psi \pi)$, which occurs in extreme drought situations in which plants attempt 
to not lose water through the transpiration process. However, plants usually have the typical water potential Istem and RWC values typical to actively grow, with well-watered trees grown in commercial grove situations on warm sunny days [121,133].

In this case, the transcellular water movement that occurs through aquaporins is very important. Thus, in citrus, from the RNA-seq results obtained in Carrizo citrange and Citrus macrophylla grafted onto the Valencia delta seedless variety, it was seen that at low temperature for Carrizo citrange plants that the expression of putative aquaporins PIP1-2, PIP2-2, and PIP2-5 is higher in relation to the low-temperature-sensitive rootstock Citrus macrophylla [134], which could be associated with a better use of transcellular water and more tolerance to stress due to low temperatures in the long term, as in other species $[129,135,136]$.

\subsection{Biochemical Response}

As a broad definition, osmoprotectants are small compounds with a neutral electrical charge and low-toxicity organic solutes. They accumulate in large quantities in cells and compensate the imbalance that occurs in the extracellular space when stress occurs. Thanks to their high solubility and them barely interfering with metabolic pathways, they are also called compatible solutes.

\subsubsection{Osmoprotectors and Low Temperature}

Temperate zone plant species acclimatize to the environment in autumn by redirecting their metabolism toward the synthesis of cryoprotective molecules like soluble sugars (sucrose, raffinose, stachyose, trehalose), sugar-alcohol (sorbitol, ribitol, inositol) and lowmolecular-weight nitrogenous compounds (proline, glycine, betaine). They also contribute to the synthesis of protein dehydrins, COR and HSPs (heat shock proteins) to stabilize phospholipids, membrane proteins, and cytoplasmic proteins by maintaining hydrophobic interactions and homeostasis, and eliminating ROS. Other solutes are released from the symplast and protect the plasma membrane from ice adhesion and subsequent cell disruption, as discussed above [137-140].

Proline

Proline is an amino acid that acts as an osmoprotector. It performs many functions in the cell, but it particularly plays a key role in osmotic adjustment by increasing the ability to resist cell dehydration. Proline is capable of accumulating in some species like citrus $[18,141,142] \mathrm{y}$ in the presence of certain abiotic stresses, i.e., salinity, drought, waterlogging and temperature stress (heat, cold, freezing) [143-148]. Proline performs its functions at the cellular level by promoting the stabilization of subcellular structures and membranes, the stabilization of proteins upon denaturation, and the detoxification and maintenance of ROS $[145,146]$.

Proline in plants is synthesized mainly from amino acid glutamate (Figure 4), which is reduced in the cytosol to glutamate-5-semialdehyde (GSA) by pyrroline-5-carboxylateosyntases 1 and 2 (P5CS1 and P5SC2) and is spontaneously converted into pyrroline-5-carboxylate (P5C). P5C reductase (P5CR) reduces $\mathrm{P} 5 \mathrm{C}$ in proline. However, proline catabolism occurs in mitochondria via proline dehydrogenase ( $\mathrm{PDH})$, which produces $\mathrm{P} 5 \mathrm{C}$ again, as well as delta 1-pyrroline-5-carboxylate dehydrogenase ( $\mathrm{P} 5 \mathrm{CDH})$, which converts $\mathrm{P} 5 \mathrm{C}$ into glutamate. Alternatively, proline can also be synthesized by another route from ornithine, which is transaminated in mitochondria by delta ornithine aminotranferase (dOAT) to produce GSA and P5C, which is then converted into proline [143,144,146,149].

\section{Anthocyanins}

Anthocyanins are not considered to be osmoprotective molecules, but are known to play a key role in some abiotic stresses, such as low temperature, given their properties, such as antioxidant and ROS detoxification [150]. As previously cited, pigmented citrus 
varieties turn out to have a high anthocyanin content, which makes them very interesting to study.

a

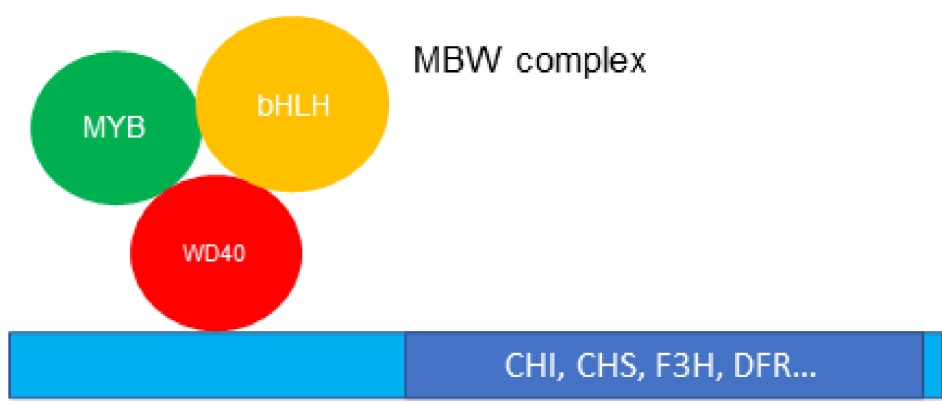

b

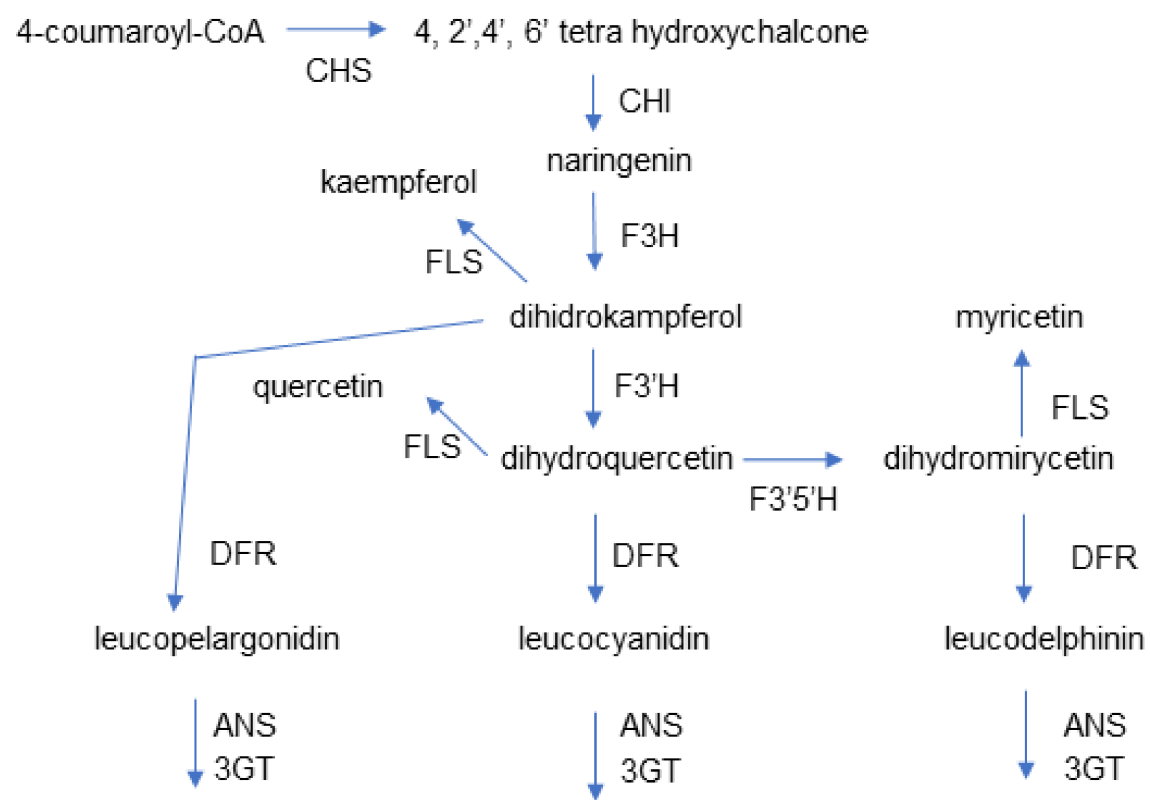

pelargonidin 3-O-glucoside cyanidin 3-O-glucoside

delphinidin 3-O-glucoside

Figure 4. Schematic representation of the anthocyanin pathway. (a) Sketch of the MBW anthocyanin pathway activation complex and (b) genes that encode their biosynthesis enzymes; CHS (chalcone synthetase), CHI (chalcone isomerase), FLS (flavonol synthetase), F3H (flavonone 3'-hydroxylase), F3'H (flavonoid 3'-hydroxylase), F3' $5^{\prime} \mathrm{H}$ (flavonoid $3^{\prime} 5^{\prime}$ hydroxylase), DFR (dihydroflavonol 4-reductase), ANS (anthocyanidin synthetase), and UFGT or 3GT (UDP-glucoseflavonoid glucosyl transferase).

Anthocyanins are water-soluble pigments from the flavonoid family and are to processes like development, defense and adaptation to unfavorable environments, such as damage from excess UV light and cold [151], as stated above. Anthocyanins are glycosides and acylglycosides of anthocyanidins.

Free anthocyanins are synthesized by the secondary route of flavonoids, and their biosynthesis enzymes are well characterized. Biosynthesis gene activation is regulated by an MBW complex formed by three transcription factors, MYB, bHLH, and WD40, and the MYB transcription factor change depending on the activation gene pathway (Figure 4a) [152,153]. It was demonstrated that the MBW complex is conserved in different species and in active CHI, CHS, F3H, and DFR genes in grapefruit [153] and in PAL, CHS, DFR, ANS, UFGT, and GST in citrus pigmented species [154-156] Biosynthesis begins from amino acid phenylalanine, which becomes a trans-cinnamic acid by the elimination of an 
ammonium group by the PAL enzyme (phenylalanine ammonium lyase). In the following steps, four hydroxylations of trans-cinnamic acid take place, which generates $p$-coumaric acid. This is carried out by the $\mathrm{C} 4 \mathrm{H}$ enzyme (cinnamate 4 hydroxylase). $p$-coumaric acid is then activated by $4 \mathrm{CL}$ (4-coumarate-CoA ligase). The first enzyme in the anthocyanin biosynthesis pathway is CHS (chalcone synthetase), which condenses the malonyl-CoA and p-coumaronyl-CoA molecules (Figure $4 \mathrm{~b}$ ) to produce narengin chalcone, which is involved in both the anthocyanin biosynthesis process and the synthesis of phenolic compounds. The narengin chalcone is then isomerized by CHI (for its initials chalcone isomerase) to flavanone narengin, which is then converted into dihydrokaempferol by $\mathrm{F} 3 \mathrm{H}$ (flavonone 3'-hydroxylase). Dihydrokaempferol is the starting point of three more compounds, dihydroflavonol, hydroquercitin and dihydromyricetin, which are the result of the reactions catalyzed by F3'H and F3'5'H (flavonoid 3'hydroxylase and flavonoid 3'5'hydroxylase, respectively). Subsequently, dihydroflavonol 4-reductase (DFR) can reduce dihydroflavonols in their respective leucoanthocyanidins (leucopelargonin, leucocyanidin and leucodelphinidin). Finally, anthocyanidin synthetase (ANS) converts leucoanthocyanidins into anthocyanidins, and confers the characteristic color to all three pigments. Once formed (pelargonidin, cyanidin and delphinidin), pigments have to be modified to their active form so that UDP-glucose-flavonoid glucosyl transferase (UFGT) catalyzes the addition of glucose to the 3-OH position of anthocyanidins to increase its hydrophobicity and stability [152].

\subsubsection{Osmoprotectors in Citrus under Cold Stress}

In citrus, the increase in the content of osmoprotectors is a preserved response to low temperature stress, with numerous studies in citrus demonstrating this. A relevant work on the synthesis of sugars and starch was conducted in Citrus junos. It carried out a proteomics work and bioinformatics analysis, which revealed that most differential abundance protein species (DAPS) participated in starch and sucrose metabolism based on the COG, KEGG, and protein interaction network analyses [91]. For instance, starch synthase (A0A067H6P7), 1,4-alpha-glucan-branching enzyme 1 (A0A2H5PA48), and glucose-1-phosphate adenylyltransferase (V4S7Z6) were down-accumulated protein species, while a polygalacturonase (A0A067H357) and mannitol dehydrogenase (A0A2H5Q4U0) were up-accumulated protein species under cold stress [91]. Furthermore, the physiological data also demonstrated that the contents of glucose, fructose, and soluble starch significantly increased [91]. A relevant work on the Poncirus trifoliata rootstock isolated the PtrBAM1 gene and overexpressed it in tobacco plants. Overexpressing plants leads to increased starch degradation, maltose, and soluble sugars compared to citrus lemon plants [157]. Moreover, the bioinformatics analysis and yeast one-hybrid showed that the PtrBAM1 promoter possessed a recognition zone in the PtrCBF gene [157].

Apart from the proline amino acid conferring tolerance to cold, it has been found to be of much help for selecting tolerant genotypes in citrus [9,92,93,158]. In two works carried out by Abouzar Abouzari, two markers associated with proline content on chromosomes 5 and 8 (CT21 and GT03, respectively) were selected based on the association of the physiological results with molecular markers [92,93].

The anthocyanin synthesis response to cold is also widely known and conserved in citrus fruits, with numerous works showing this fact, where apart from measuring the concentration of anthocyanins and flavonoids, they quantify the gene expression of biosynthesis genes by comparing it among several citrus genotypes [95,159-164]. Angela Roberta Lo Piero's group has analyzed the anthocyanin synthesis route in citrus. One of her works focuses on analyzing the transcriptome of the pigmented citrus variety Tarocco Sciara [95]. The same work observed the enhancement of the transcripts involved in intense rearranging activity of membrane lipids, mainly to address lipid desaturation by encoding enzymes which form part of both defense mechanisms against oxidative damage and processes that adjust the cell osmotic potential, as well as many ESTs of the genes implicated in primary and secondary metabolisms. In particular, its results 
showed that cold stress induces transcriptome modifications, undoubtedly toward the enhancement of both the flavonoid biosynthesis pathways. Those authors propose that the rise in anthocyanin levels that occurs in oranges subjected to cold stress might contribute to control the cell osmotic potential [95].

\subsection{Hormones and Stress Due to Low Temperatures}

\subsubsection{ABA and Cold}

In higher plants, ABA regulates several aspects of plant growth, such as seed development and maturation, germination and stomatal closure $[165,166]$. The ABA response is necessary for the transcriptional activation of the genes involved in dehydration, low temperature, and other stresses $[149,167]$. The activation of the ABA response genes leads to the synthesis of the proteins belonging to different families, including the chloroplastic proteins involved in photosynthesis, and in ROS production and detoxification [168]. Other ABA-regulated genes encode transcription factors, chaperones, osmolyte synthesis enzymes, LEA proteins, and COR proteins [169-172].

ABA response is induced by the activation of several protein kinases, including SnRK2s, CPK3, SOS2, CIPK24, and CIPK23 in Arabidopsis, and MdCIPk22 in apple, which affect changes in the phosphorylation of many downstream regulators [60,173-180].

It is known that once the binding between ABA and its PYL receptors takes place, it interacts with type A PP2Cs which, in turn, releases the inhibition of SnRK2.2/3/6 [179-185].

Increased $\mathrm{ABA}$ hormone concentration correlates with greater $\mathrm{ABA}$ biosynthesis in Arabidopsis and rice [186,187], and occurs in response to cold stress in several species. The exogenous application of the $\mathrm{ABA}$ hormone promotes low temperature stress tolerance, and $\mathrm{ABA}$ mutants exhibit altered resistance. However, it is thought that ABA does not act at the level of CBF genes expression, but at the upstream control [188-190].

\subsubsection{Jasmonic Acid and Cold}

Jasmonic acid (JA) is a hormone that intervenes in biotic and abiotic stresses that is thought to suppress growth in the presence of cold stress. JA is an oxilipin hormonetype whose concentration increases in cold stress in different plant species, including maize, rice, and Arabidopsis [187,191-193]. A rise in the JA concentration correlates with the increased expression of the biosynthesis genes in Arabidopsis and rice [191,192] and the repression of the genes that code for genes involved in the catabolism of JA in rice [191]. Once the concentration of JA increases, binding occurs with its COI1 receptor and ubiquitination signaling begins. Thus, the proteasome-dependent degradation of JAZ proteins is stimulated, which repress the expression of the JA response genes. Exogenous JA application enhances the induction of the CBFs and CBFs upstream genes after low temperature treatment and promotes cold tolerance. In Arabidopsis, repressors JAZ1 and JAZ4 are thought to interact directly with transcription factors ICE1 and ICE2 to directly repress their effect [192]. A microarray assay in coil mutant plants has shown that some of the COR genes corresponding to the CBF-independent pathway were altered [192].

\subsubsection{ABA and JAs in Citrus under Cold Stress}

Citrus exposed to low temperatures was also affected by ABA and jasmonic hormones, and several studies were carried out in which response to cold is involved [79,84,194,195].

Other studies were also conducted on citrus by applying exogenous ABA, which responded to low temperatures. One study has indicated that foliar ABA applied to citrus effectively increases freeze tolerance if $\mathrm{ABA}$ is applied 3 days before the freezing event takes place, but it does not occur when ABA is applied in soil [196]. Subsequently, another ABA application experiment was carried out to compare Poncirus trifoliata vs. Citrus limonia, and leaves were treated with ABA exposed to low temperatures. Pretreatment with abscisic acid can significantly reduce the membrane damage caused by freezing stress. However, the lipid peroxidation damage caused by low temperature and activities of antioxidant enzymes are irregularly influenced by ABA pretreatment [197]. 


\section{Conclusions}

This synthesis work of our knowledge about abiotic stress due to low temperatures in citrus fruits was conducted given the need to find answers to this very interesting stress type caused by climate change.

Acquiring further knowledge about rootstocks/variety interactions has allowed us to advance in grafting techniques and to better select plant material from plant breeding programs. The physiological changes caused by low temperatures were known since the 1980s and 1990s $[18,21,43]$. Stopping photosynthesis, water potential, chlorophyll degradation, and the synthesis of compatible solutes are examples of responses that take place without knowing why. Thanks to the analysis of transcriptomes and genomes, this knowledge sheds light on the lack of knowledge.

In recent years, the most immediate response to low temperatures has become known in model organisms like Arabidopsis thaliana. This fact greatly facilitates extrapolating these findings to other horticultural or arboreal species absent in a multitude of loss and gain-of-function mutants.

Author Contributions: A.P.-C., writing—original draft preparation; M.-R.M.-C., review and editing; M.Á.F.-G., conceptualization and review. All authors have read and agreed to the published version of the manuscript.

Funding: This study was cofounded by the Ministerio de Ciencia e Innovación (RTI2018-098379-RI00) and by the European Union through the European Regional Development Fund (ERDF) of the Generalitat Valenciana 2014-2020 (IVIA-51913).

Institutional Review Board Statement: Not applicable.

Informed Consent Statement: Not applicable.

Data Availability Statement: Not applicable.

Conflicts of Interest: The authors declare no conflict of interest.

\section{References}

1. Cohen, J.; Jones, J.; Furtado, J.; Tziperman, E. Warm Arctic, Cold Continents: A Common Pattern Related to Arctic Sea Ice Melt, Snow Advance, and Extreme Winter Weather. Oceanography 2013, 26, 150-160. [CrossRef]

2. Kodra, E.; Steinhaeuser, K.; Ganguly, A.R. Persisting cold extremes under 21st-century warming scenarios. Geophys. Res. Lett. 2011, 38, L08705. [CrossRef]

3. Rosenzweig, C.; Iglesius, A.; Yang, X.B.; Epstein, P.; Chivian, E. Climate change and extreme weather events-Implications for food production, plant diseases, and pests. Global Change Human Health 2021, 2, 90-104. [CrossRef]

4. Trouet, V.; Babst, F.; Meko, M. Recent enhanced high-summer North Atlantic Jet variability emerges from three-century context. Nat. Commun. 2018, 9, 180. [CrossRef] [PubMed]

5. Warschefsky, E.J.; Klein, L.L.; Frank, M.H.; Chitwood, D.H.; Londo, J.P.; von Wettberg, E.J.B.; Miller, A.J. Rootstocks: Diversity, Domestication, and Impacts on Shoot Phenotypes. Trends Plant Sci. 2016, 21, 418-437. [CrossRef] [PubMed]

6. Albrecht, U.; McCollum, G.; Bowman, K.D. Influence of rootstock variety on Huanglongbing disease development in field-grown sweet orange (Citrus sinensis [L.] Osbeck) trees. Sci. Hortic. 2012, 138, 210-220. [CrossRef]

7. Castle, W.S. A Career Perspective on Citrus Rootstocks, Their Development, and Commercialization. HortScience 2010, 45, 11-15. [CrossRef]

8. Martínez-Cuenca, M.-R.; Primo-Capella, A.; Forner-Giner, M.A. Key role of boron compartmentalisation-related genes as the initial cell response to low B in citrus genotypes cultured in vitro. Hortic. Environ. Biotechnol. 2019, 60, 519-530. [CrossRef]

9. Primo-Capella, A.; Martínez-Cuenca, M.-R.; Gil-Muñoz, F.; Forner-Giner, M.A. Physiological characterization and proline route genes quantification under long-term cold stress in Carrizo citrange. Sci. Hortic. 2021, 276, 109744. [CrossRef]

10. Morales, J.; Bermejo, A.; Navarro, P.; Forner-Giner, M.Á.; Salvador, A. Rootstock effect on fruit quality, anthocyanins, sugars, hydroxycinnamic acids and flavanones content during the harvest of blood oranges 'Moro' and 'Tarocco Rosso' grown in Spain. Food Chem. 2020, 342, 128305. [CrossRef]

11. Forner-Giner, M.A.-M. Performance of Forner-Alcaide 5 and Forner-Alcaide 13, hybrids of Cleopatra mandarin $x$ Poncirus trifoliate, as Salinity-Tolerant Citrus Rootstocks. J. Am. Pomol. Soc. 2009, 63, 72.

12. Kim, M.; Canio, W.; Kessler, S.; Sinha, N. Developmental Changes Due to Long-Distance Movement of a Homeobox Fusion Transcript in Tomato. Science 2001, 293, 287. [CrossRef]

13. Kudo, H.; Harada, T. A Graft-transmissible RNA from Tomato Rootstock Changes Leaf Morphology of Potato Scion. HortScience 2007, 42, 225-226. [CrossRef] 
14. Thieme, C.J.; Rojas-Triana, M.; Stecyk, E.; Schudoma, C.; Zhang, W.; Yang, L.; Miñambres, M.; Walther, D.; Schulze, W.X.; Paz-Ares, J.; et al. Endogenous Arabidopsis messenger RNAs transported to distant tissues. Nat. Plants 2015, 1, 15025. [CrossRef]

15. Attaway, J.A. A History of Florida Citrus Freezes; Florida Science Source: Ocala, FL, USA, 1997; ISBN 978-0-944961-03-2.

16. Hara, M.; Terashima, S.; Fukaya, T.; Kuboi, T. Enhancement of cold tolerance and inhibition of lipid peroxidation by citrus dehydrin in transgenic tobacco. Planta 2003, 217, 290-298. [CrossRef]

17. Sakai, A.; Larcher, W. Frost Survival of Plants: Responses and Adaptation to Freezing Stress; Springer Science \& Business Media: Berlin/Heidelberg, Germany, 2012; ISBN 978-3-642-71745-1.

18. Yelenosky, G. Accumulation of Free Proline in Citrus Leaves during Cold Hardening of Young Trees in Controlled Temperature Regimes. Plant Physiol. 1979, 64, 425-427. [CrossRef]

19. Soler, J.; Soler, G. Cítricos: Variedades y Técnicas de Cultivo; Ediciones Mundi-Prensa: Madrid, Spain, 2018 ; ISBN 10-8484762971.

20. Rebolledo Roa, A. Fisiología de la Floración y Fructificación en Los Cítricos; Corporación Universitaria Lasallista: Lasallista, Colombia, 2012; ISBN 978-958-8406-17-6.

21. Vu, J.C.V.; Yelenosky, G. Photosynthesis and freeze tolerance comparisons of the newly released "ambersweet" hybrid with "valencia" orange. Environ. Exp. Bot. 1993, 33, 391-395. [CrossRef]

22. Nesbitt, M.L.; Ebel, R.C.; Findley, D.; Wilkins, B.; Woods, F.; Himelrick, D. Assays to Assess Freeze Injury of Satsuma Mandarin. HortScience 2002, 37, 871-877. [CrossRef]

23. Vu, J.C.V.; Yelenosky, G. Photosynthetic responses of citrus trees to soil flooding. Physiol. Plant. 1991, 81, 7-14. [CrossRef]

24. Inch, S.; Stover, E.; Driggers, R.; Lee, R.F. Freeze Response of Citrus and Citrus-related Genotypes in a Florida Field Planting. HortScience 2014, 49, 1010-1016. [CrossRef]

25. Peng, T.; Zhu, X.F.; Fan, Q.J.; Sun, P.P.; Liu, J.H. Identification and characterization of low temperature stress responsive genes in Poncirus trifoliata by suppression subtractive hybridization. Gene 2012, 492, 220-228. [CrossRef]

26. Wang, M.; Zhang, X.; Liu, J.-H. Deep sequencing-based characterization of transcriptome of trifoliate orange (Poncirus trifoliata (L.) Raf.) in response to cold stress. BMC Genom. 2015, 16, 555. [CrossRef]

27. Martínez-Cuenca, M.-R.; Iglesias, D.J.; Forner-Giner, M.A.; Primo-Millo, E.; Legaz, F. The effect of sodium bicarbonate on plant performance and iron acquisition system of FA-5 (Forner-Alcaide 5) citrus seedlings. Acta Physiol. Plant. 2013, 35, $2833-2845$. [CrossRef]

28. Martínez-Cuenca, M.-R.; Quiñones, A.; Forner-Giner, M.Á. Screening of 'King' mandarin (Citrus nobilis Lour) $\times$ Poncirus trifoliata ((L.) Raf.) hybrids as citrus rootstocks tolerants to iron chlorosis. Sci. Hortic. 2016, 198, 61-69. [CrossRef]

29. Martinez-Cuenca, M.-R.; Primo-Capella, A.; Uiñones, A.; Bermejo, A.; Forner-Giner, M.A. Rootstock influence on iron uptake responses in Citrus leaves and their regulation under the Fe paradox effect. PeerJ 2017, 2017, e3553. [CrossRef] [PubMed]

30. Forner, J.B.; Forner-Giner, M.A.; Alcaide, A. Forner-Alcaide 5 and Forner-Alcaide 13: Two New Citrus Rootstocks Released in Spain. HortScience 2003, 38, 629-630. [CrossRef]

31. Forner-Giner, M.; Alcaide, A.; Primo-Millo, E.; Forner, J. Performance of 'Navelina' orange on 14 rootstocks in Northern Valencia (Spain). Sci. Hortic. 2003, 98, 223-232. [CrossRef]

32. Forner-Giner, M.A.; Rodriguez-Gamir, J.; Martinez-Alcantara, B.; Quiñones, A.; Iglesias, D.J.; Primo-Millo, E.; Forner, J. Performance of Navel orange trees grafted onto two new dwarfing rootstocks (Forner-Alcaide 517 and Forner-Alcaide 418). Sci. Hortic. 2014, 179, 376-387. [CrossRef]

33. González-Mas, M.C.; Llosa, M.J.; Quijano, A.; Forner-Giner, M.A. Rootstock Effects on Leaf Photosynthesis in 'Navelina' Trees Grown in Calcareous Soil. HortScience 2009, 44, 280-283. [CrossRef]

34. Martínez-Cuenca, M.-R.; Forner-Giner, M.Á.; Iglesias, D.J.; Primo-Millo, E.; Legaz, F. Strategy I responses to Fe-deficiency of two Citrus rootstocks differing in their tolerance to iron chlorosis. Sci. Hortic. 2013, 153, 56-63. [CrossRef]

35. Davies, F.S.; Albrigo, L.G. Citrus; CAB International: Wallingford, UK, 1994; ISBN 0851988679.

36. Joublan, J.P.; Cordero, N. Comportamiento de algunos cítricos sobre diferentes portainjertos, en su tercera temporada de crecimiento, quillón viii región, chile. Agric. Técnica 2002, 62, 469-479. [CrossRef]

37. Liu, X.; Li, J.; Huang, M.; Chen, J. Mechanisms for the Influence of Citrus Rootstocks on Fruit Size. J. Agric. Food Chem. 2015, 63, 2618-2627. [CrossRef] [PubMed]

38. Dubey, A.K.; Sharma, R.M. Effect of rootstocks on tree growth, yield, quality and leaf mineral composition of lemon (Citrus limon (L.) Burm.). Sci. Hortic. 2016, 200, 131-136. [CrossRef]

39. Gil-Izquierdo, A.; Riquelme, M.T.; Porras, I.; Ferreres, F. Effect of the Rootstock and Interstock Grafted in Lemon Tree (Citrus limon (L.) Burm.) on the Flavonoid Content of Lemon Juice. J. Agric. Food Chem. 2004, 52, 324-331. [CrossRef]

40. Rapisarda, P.; Giuffrida, A. Anthocyanins level in Italian blood oranges. Proc. Int. Soc. Citric. 1992, 3, $1130-1133$.

41. de Pascual-Teresa, S.; Sanchez-Ballesta, M.T. Anthocyanins: From plant to health. Phytochem. Rev. 2008, 7, 281-299. [CrossRef]

42. Oustric, J.; Morillon, R.; Luro, F.; Herbette, S.; Lourkisti, R.; Giannettini, J.; Berti, L.; Santini, J. Tetraploid Carrizo citrange rootstock (Citrus sinensis Osb. $\times$ Poncirus trifoliata L. Raf.) enhances natural chilling stress tolerance of common clementine (Citrus clementina Hort. ex Tan). J. Plant Physiol. 2017, 214, 108-115. [CrossRef]

43. Yelenosky, G. Cold Hardiness in Citrus. In Horticultural Reviews; Janick, J., Ed.; John Wiley \& Sons, Inc.: Hoboken, NJ, USA, 1985; pp. 201-238. ISBN 978-1-118-06073-5. 
44. Primo-Capella, A.; Forner-Giner, M.A.; Martínez-Cuenca, M.R.; Terol, J. Comparative transcriptomic analyses of Citrus coldresistant vs. sensitive rootstocks suggest a crucial role of ABA signaling in triggering cold scion adaption. BMC Plant Biol. 2021. under review, submitted on 23 April 2021.

45. Thomashow, M.F. Role of Cold-Responsive Genes in Plant Freezing Tolerance. Plant Physiol. 1998, 118, 1-8. [CrossRef]

46. Liu, Y.; Dang, P.; Liu, L.; He, C. Cold acclimation by the CBF-COR pathway in a changing climate: Lessons from Arabidopsis thaliana. Plant Cell Rep. 2019, 38, 511-519. [CrossRef]

47. Steponkus, P.L. Role of the Plasma Membrane in Freezing Injury and Cold Acclimation. Annu. Rev. Plant Physiol. 1984, 35, 543-584. [CrossRef]

48. Steponkus, P.L.; Webb, M.S. Freeze-Induced Dehydration and Membrane Destabilization in Plants. In Proceedings of the Water and Life; Somero, G.N., Osmond, C.B., Bolis, C.L., Eds.; Springer: Berlin/Heidelberg, Germany, 1992; pp. 338-362.

49. Lynch, D.V.; Steponkus, P.L. Plasma Membrane Lipid Alterations Associated with Cold Acclimation of Winter Rye Seedlings (Secale cereale L. cv Puma). Plant Physiol. 1987, 83, 761-767. [CrossRef] [PubMed]

50. Uemura, M.; Joseph, R.A.; Steponkus, P.L. Cold Acclimation of Arabidopsis thaliana (Effect on Plasma Membrane Lipid Composition and Freeze-Induced Lesions). Plant Physiol. 1995, 109, 15. [CrossRef] [PubMed]

51. Knight, H. Calcium Signaling during Abiotic Stress in Plants. In International Review of Cytology; Jeon, K.W., Ed.; Academic Press: Cambridge, MA, USA, 1999; Volume 195, pp. 269-324.

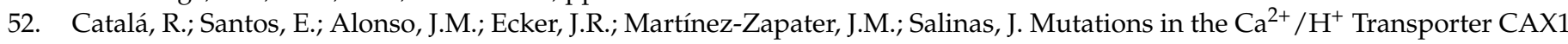
Increase CBF/DREB1 Expression and the Cold-Acclimation Response in Arabidopsis. Plant Cell 2003, 15, 2940-2951. [CrossRef] [PubMed]

53. Knight, M.R.; Knight, H. Low-temperature perception leading to gene expression and cold tolerance in higher plants. New Phytol. 2012, 195, 737-751. [CrossRef]

54. Shinozaki, K.; Yamaguchi-Shinozaki, K. Molecular responses to drought and cold stress. Curr. Opin. Biotechnol. 1996, 7, 161-167. [CrossRef]

55. Yang, T.; Chaudhuri, S.; Yang, L.; Du, L.; Poovaiah, B.W. A calcium/calmodulin-regulated member of the receptor-like kinase family confers cold tolerance in plants. J. Biol. Chem. 2010, 285, 7119-7126. [CrossRef]

56. Zhao, C.; Wang, P.; Si, T.; Hsu, C.-C.; Wang, L.; Zayed, O.; Yu, Z.; Zhu, Y.; Dong, J.; Tao, W.A.; et al. MAP Kinase Cascades Regulate the Cold Response by Modulating ICE1 Protein Stability. Dev. Cell 2017, 43, 618-629.e5. [CrossRef]

57. Liu, Y. Roles of mitogen-activated protein kinase cascades in ABA signaling. Plant Cell Rep. 2012, 31, 1-12. [CrossRef]

58. Liu, Y.; He, C. A review of redox signaling and the control of MAP kinase pathway in plants. Redox Biol. 2017, 11, 192-204. [CrossRef]

59. Chinnusamy, V.; Ohta, M.; Kanrar, S.; Lee, B.; Hong, X.; Agarwal, M.; Zhu, J.-K. ICE1: A regulator of cold-induced transcriptome and freezing tolerance in Arabidopsis. Genes Dev. 2003, 17, 1043-1054. [CrossRef]

60. Ding, Y.; Li, H.; Zhang, X.; Xie, Q.; Gong, Z.; Yang, S. OST1 Kinase Modulates Freezing Tolerance by Enhancing ICE1 Stability in Arabidopsis. Dev. Cell 2015, 32, 278-289. [CrossRef]

61. Su, C.; Chen, K.; Ding, Q.; Mou, Y.; Yang, R.; Zhao, M.; Ma, B.; Xu, Z.; Ma, Y.; Pan, Y.; et al. Proteomic Analysis of the Function of a Novel Cold-Regulated Multispanning Transmembrane Protein COR413-PM1 in Arabidopsis. Int. J. Mol. Sci. 2018, 19, 2572. [CrossRef]

62. Miura, K.; Jin, J.B.; Lee, J.; Yoo, C.Y.; Stirm, V.; Miura, T.; Ashworth, E.N.; Bressan, R.A.; Yun, D.-J.; Hasegawa, P.M. SIZ1-Mediated Sumoylation of ICE1 Controls CBF3/DREB1A Expression and Freezing Tolerance in Arabidopsis. Plant Cell 2007, 19, 1403-1414. [CrossRef]

63. Li, H.; Ding, Y.; Shi, Y.; Zhang, X.; Zhang, S.; Gong, Z.; Yang, S. MPK3- and MPK6-Mediated ICE1 Phosphorylation Negatively Regulates ICE1 Stability and Freezing Tolerance in Arabidopsis. Dev. Cell 2017, 43, 630-642.e4. [CrossRef]

64. Dong, C.-H.; Agarwal, M.; Zhang, Y.; Xie, Q.; Zhu, J.-K. The negative regulator of plant cold responses, HOS1, is a RING E3 ligase that mediates the ubiquitination and degradation of ICE1. Proc. Natl. Acad. Sci. USA 2006, 103, 8281-8286. [CrossRef]

65. Thomashow, M.F. Molecular Basis of Plant Cold Acclimation: Insights Gained from Studying the CBF Cold Response Pathway. Plant Physiol. 2010, 154, 571-577. [CrossRef]

66. Benedict, C.; Skinner, J.S.; Meng, R.; Chang, Y.; Bhalerao, R.; Huner, N.P.A.; Finn, C.E.; Chen, T.H.H.; Hurry, V. The CBF1dependent low temperature signalling pathway, regulon and increase in freeze tolerance are conserved in Populus spp. Plant Cell Environ. 2006, 29, 1259-1272. [CrossRef] [PubMed]

67. Wisniewski, M.; Norelli, J.; Bassett, C.; Artlip, T.; Macarisin, D. Ectopic expression of a novel peach (Prunus persica) CBF transcription factor in apple (Malus $\times$ domestica) results in short-day induced dormancy and increased cold hardiness. Planta 2011, 233, 971-983. [CrossRef] [PubMed]

68. Agarwal, M.; Hao, Y.; Kapoor, A.; Dong, C.-H.; Fujii, H.; Zheng, X.; Zhu, J.-K. A R2R3 Type MYB Transcription Factor Is Involved in the Cold Regulation of CBF Genes and in Acquired Freezing Tolerance. J. Biol. Chem. 2006, 281, 37636-37645. [CrossRef]

69. Kim, S.H.; Kim, H.S.; Bahk, S.; An, J.; Yoo, Y.; Kim, J.-Y.; Chung, W.S. Phosphorylation of the transcriptional repressor MYB15 by mitogen-activated protein kinase 6 is required for freezing tolerance in Arabidopsis. Nucleic Acids Res. 2017, 45, 6613-6627. [CrossRef] [PubMed]

70. Yano, R.; Nakamura, M.; Yoneyama, T.; Nishida, I. Starch-Related $\alpha$-Glucan/Water Dikinase Is Involved in the Cold-Induced Development of Freezing Tolerance in Arabidopsis. Plant Physiol. 2005, 138, 837-846. [CrossRef] 
71. Doherty, C.J.; Van Buskirk, H.A.; Myers, S.J.; Thomashow, M.F. Roles for Arabidopsis CAMTA Transcription Factors in ColdRegulated Gene Expression and Freezing Tolerance. Plant Cell 2009, 21, 972-984. [CrossRef]

72. Kidokoro, S.; Yoneda, K.; Takasaki, H.; Takahashi, F.; Shinozaki, K.; Yamaguchi-Shinozaki, K. Different Cold-Signaling Pathways Function in the Responses to Rapid and Gradual Decreases in Temperature. Plant Cell 2017, 29, 760-774. [CrossRef]

73. Maibam, P.; Nawkar, G.M.; Park, J.H.; Sahi, V.P.; Lee, S.Y.; Kang, C.H. The influence of light quality, circadian rhythm, and photoperiod on the CBF-mediated freezing tolerance. Int. J. Mol. Sci. 2013, 14, 11527-11543. [CrossRef] [PubMed]

74. Franklin, K.A.; Whitelam, G.C. Light-quality regulation of freezing tolerance in Arabidopsis thaliana. Nat. Genet. 2007, 39, 1410-1413. [CrossRef] [PubMed]

75. Catalá, R.; Medina, J.; Salinas, J. Integration of low temperature and light signaling during cold acclimation response in Arabidopsis. Proc. Natl. Acad. Sci. USA 2011, 108, 16475-16480. [CrossRef] [PubMed]

76. Shin, J.; Park, E.; Choi, G. PIF3 regulates anthocyanin biosynthesis in an HY5-dependent manner with both factors directly binding anthocyanin biosynthetic gene promoters in Arabidopsis. Plant J. 2007, 49, 981-994. [CrossRef]

77. M.; Moore, G.A. Identification and expression analysis of cold-regulated genes from the cold-hardy Citrus relative Poncirus trifoliata (L.) Raf. Plant Mol. Biol. 2006, 62, 83-97. [CrossRef] [PubMed]

78. Champ, K.I.; Febres, V.J.; Moore, G.A. The role of CBF transcriptional activators in two Citrus species (Poncirus and Citrus) with contrasting levels of freezing tolerance. Physiol. Plant 2007, 129, 529-541. [CrossRef]

79. Ouyang, Z.G.; Mi, L.F.; Duan, H.H.; Hu, W.; Chen, J.M.; Peng, T.; Zhong, B.L. Differential expressions of citrus CAMTAs during fruit development and responses to abiotic stresses. Biol. Plant. 2019, 63, 354-364. [CrossRef]

80. Meng, S.; Dane, F.; Si, Y.; Ebel, R.; Zhang, C. Gene expression analysis of cold treated versus cold acclimated Poncirus trifoliata. Euphytica 2008, 164, 209. [CrossRef]

81. Huang, X.-S.; Wang, W.; Zhang, Q.; Liu, J.-H. A Basic Helix-Loop-Helix Transcription Factor, PtrbHLH, of Poncirus trifoliata Confers Cold Tolerance and Modulates Peroxidase-Mediated Scavenging of Hydrogen Peroxide. Plant Physiol. 2013, $162,1178$. [CrossRef]

82. Huang, X.-S.; Zhang, Q.; Zhu, D.; Fu, X.; Wang, M.; Zhang, Q.; Moriguchi, T.; Liu, J.-H. ICE1 of Poncirus trifoliata functions in cold tolerance by modulating polyamine levels through interacting with arginine decarboxylase. J. Exp. Bot. 2015, 66, 3259-3274. [CrossRef]

83. Geng, J.; Wei, T.; Wang, Y.; Huang, X.; Liu, J.-H. Overexpression of PtrbHLH, a basic helix-loop-helix transcription factor from Poncirus trifoliata, confers enhanced cold tolerance in pummelo (Citrus grandis) by modulation of $\mathrm{H}_{2} \mathrm{O}_{2}$ level via regulating a CAT gene. Tree Physiol. 2019, 39, 2045-2054. [CrossRef]

84. Liu, D.-C.; He, L.-G.; Wang, H.-L.; Xu, M.; Sun, Z.-H. Molecular cloning, characterization and expression analysis of PtrHOS1, a novel gene of cold responses from trifoliate orange [Poncirus trifoliata (L.) Raf.]. Acta Physiol. Plant. 2010, 32, 271-279. [CrossRef]

85. He, L.G.; Wang, H.L.; Liu, D.C.; Zhao, Y.J.; Xu, M.; Zhu, M.; Wei, G.Q.; Sun, Z.H. Isolation and expression of a cold-responsive gene PtCBF in Poncirus trifoliata and isolation of citrus CBF promoters. Biol. Plant. 2012, 56, 484-492. [CrossRef]

86. Huang, D.; Yuan, Y.; Tang, Z.; Huang, Y.; Kang, C.; Deng, X.; Xu, Q. Retrotransposon promoter of Ruby1 controls both light- and cold-induced accumulation of anthocyanins in blood orange. Plant. Cell Environ. 2019, 42, 3092-3104. [CrossRef]

87. He, Z.; Zhao, T.; Yin, Z.; Liu, J.; Cheng, Y.; Xu, J. The phytochrome-interacting transcription factor CsPIF8 contributes to cold tolerance in citrus by regulating superoxide dismutase expression. Plant Sci. 2020, 298, 110584. [CrossRef] [PubMed]

88. Adam, S.; Murthy, S.D.S. Effect of Cold Stress on Photosynthesis of Plants and Possible Protection Mechanisms. In Approaches to Plant Stress and Their Management; Gaur, R.K., Sharma, P., Eds.; Springer: New Delhi, India, 2014; pp. 219-226. ISBN 978-81-322-1619-3 978-81-322-1620-9.

89. Paul, M.J.; Driscoll, S.P.; Lawlor, D.W. Sink-Regulation of Photosynthesis in Relation to Temperature in Sunflower and Rape. J. Exp. Bot. 1992, 43, 147-153. [CrossRef]

90. Verslues, P.E.; Agarwal, M.; Katiyar-Agarwal, S.; Zhu, J.; Zhu, J.-K. Methods and concepts in quantifying resistance to drought, salt and freezing, abiotic stresses that affect plant water status. Plant J. 2006, 45, 523-539. [CrossRef] [PubMed]

91. Jiang, J.; Hou, R.; Yang, N.; Li, L.; Deng, J.; Qin, G.; Ding, D. Physiological and TMT-labeled proteomic analyses reveal important roles of sugar and secondary metabolism in Citrus junos under cold stress. J. Proteom. 2021, 237, 104145. [CrossRef] [PubMed]

92. Abouzari, A.; Solouki, M.; Golein, B.; Fakheri, B.A.; Sabouri, A. The change trend in physiological traits of 110 citrus accessions in response to cold stress. Bangladesh J. Bot. 2020, 49, 375-385. [CrossRef]

93. Abouzari, A.; Solouki, M.; Golein, B.; Fakheri, B.A.; Sabouri, A.; Dadras, A.R. Screening of molecular markers associated to cold tolerance- related traits in Citrus. Sci. Hortic. 2020, 263, 109145. [CrossRef]

94. Yang, L.; Ye, J.; Guo, W.-D.; Wang, C.-C.; Hu, H.-T. Differences in cold tolerance and expression of two fatty acid desaturase genes in the leaves between fingered citron and its dwarf mutant. Trees 2012, 26, 1193-1201. [CrossRef]

95. Crifò, T.; Puglisi, I.; Petrone, G.; Recupero, G.R.; Lo Piero, A.R. Expression analysis in response to low temperature stress in blood oranges: Implication of the flavonoid biosynthetic pathway. Gene 2011, 476, 1-9. [CrossRef]

96. Nordby, H.E.; Yelenosky, G. Change in citrus leaf lipids during freeze-thaw stress. Phytochemistry 1985, 24, 1675-1679. [CrossRef]

97. Maul, P.; Mccollum, G.T.; Popp, M.; Guy, C.L.; Porat, R.O.N. Transcriptome profiling of grapefruit flavedo following exposure to low temperature and conditioning treatments uncovers principal molecular components involved in chilling tolerance and susceptibility. Plant. Cell Environ. 2008, 31, 752-768. [CrossRef] 
98. Berry, J.; Bjorkman, O. Photosynthetic Response and Adaptation to Temperature in Higher Plants. Annu. Rev. Plant Physiol. 1980, 31, 491-543. [CrossRef]

99. Yamori, W.; Noguchi, K.O.; Terashima, I. Temperature acclimation of photosynthesis in spinach leaves: Analyses of photosynthetic components and temperature dependencies of photosynthetic partial reactions. Plant. Cell Environ. 2005, 28, 536-547. [CrossRef]

100. Yamori, W.; Noguchi, K.; Hanba, Y.T.; Terashima, I. Effects of Internal Conductance on the Temperature Dependence of the Photosynthetic Rate in Spinach Leaves from Contrasting Growth Temperatures. Plant Cell Physiol. 2006, 47, 1069-1080. [CrossRef] [PubMed]

101. Yamori, W.; Noguchi, K.; Kashino, Y.; Terashima, I. The Role of Electron Transport in Determining the Temperature Dependence of the Photosynthetic Rate in Spinach Leaves Grown at Contrasting Temperatures. Plant Cell Physiol. 2008, 49, 583-591. [CrossRef] [PubMed]

102. Yamori, W.; Noguchi, K.; Hikosaka, K.; Terashima, I. Phenotypic Plasticity in Photosynthetic Temperature Acclimation among Crop Species with Different Cold Tolerances. Plant Physiol. 2010, 152, 388. [CrossRef]

103. Anderson, J.M.; Chow, W.S.; Park, Y.-I. The grand design of photosynthesis: Acclimation of the photosynthetic apparatus to environmental cues. Photosynth. Res. 1995, 46, 129-139. [CrossRef]

104. Hüner, N.P.A.; Bode, R.; Dahal, K.; Hollis, L.; Rosso, D.; Krol, M.; Ivanov, A.G. Chloroplast redox imbalance governs phenotypic plasticity: The "grand design of photosynthesis" revisited. Front. Plant Sci. 2012, 3, 255. [CrossRef]

105. Hüner, N.P.A.; Dahal, K.; Bode, R.; Kurepin, L.V.; Ivanov, A.G. Photosynthetic acclimation, vernalization, crop productivity and 'the grand design of photosynthesis'. J. Plant Physiol. 2016, 203, 29-43. [CrossRef] [PubMed]

106. Gray, G.R.; Chauvin, L.P.; Sarhan, F.; Huner, N.P.A. Cold Acclimation and Freezing Tolerance (A Complex Interaction of Light and Temperature). Plant Physiol. 1997, 114, 467. [CrossRef]

107. Janda, T.; Szalai, G.; Leskó, K.; Yordanova, R.; Apostol, S.; Popova, L.P. Factors contributing to enhanced freezing tolerance in wheat during frost hardening in the light. Phytochemistry 2007, 68, 1674-1682. [CrossRef] [PubMed]

108. Majláth, I.; Szalai, G.; Soós, V.; Sebestyén, E.; Balázs, E.; Vanková, R.; Dobrev, P.I.; Tari, I.; Tandori, J.; Janda, T. Effect of light on the gene expression and hormonal status of winter and spring wheat plants during cold hardening. Physiol. Plant. 2012, 145, 296-314. [CrossRef]

109. Szalai, G.; Pap, M.; Janda, T. Light-induced frost tolerance differs in winter and spring wheat plants. J. Plant Physiol. 2009, 166, 1826-1831. [CrossRef] [PubMed]

110. Baker, N.R. Photoinhibition of Photosynthesis. In Light as an Energy Source and Information Carrier in Plant Physiology; Jennings, R.C., Zucchelli, G., Ghetti, F., Colombetti, G., Eds.; Springer: Boston, MA, USA, 1996; pp. 89-97. ISBN 978-1-4613-0409-8.

111. Aro, E.-M.; Virgin, I.; Andersson, B. Photoinhibition of Photosystem II. Inactivation, protein damage and turnover. Biochim. Biophys. Acta Bioenerg. 1993, 1143, 113-134. [CrossRef]

112. Murata, N.; Takahashi, S.; Nishiyama, Y.; Allakhverdiev, S.I. Photoinhibition of photosystem II under environmental stress. Biochim. Biophys. Acta 2007, 1767, 414-421. [CrossRef] [PubMed]

113. Powles, S.B. Photoinhibition of Photosynthesis Induced by Visible Light. Annu. Rev. Plant Physiol. 1984, 35, 15-44. [CrossRef]

114. Demmig-Adams, B.; Cohu, C.M.; Muller, O.; Adams, W.W. Modulation of photosynthetic energy conversion efficiency in nature: From seconds to seasons. Photosynth. Res. 2012, 113, 75-88. [CrossRef]

115. Gururani, M.A.; Venkatesh, J.; Tran, L.S.P. Regulation of Photosynthesis during Abiotic Stress-Induced Photoinhibition. Mol. Plant 2015, 8, 1304-1320. [CrossRef] [PubMed]

116. Tikkanen, M.; Grebe, S. Switching off photoprotection of photosystem I-a novel tool for gradual PSI photoinhibition. Physiol. Plant. 2018, 162, 156-161. [CrossRef] [PubMed]

117. Kudoh, H.; Sonoike, K. Irreversible damage to photosystem I by chilling in the light: Cause of the degradation of chlorophyll after returning to normal growth temperature. Planta 2002, 215, 541-548. [CrossRef]

118. Lourkisti, R.; Froelicher, Y.; Herbette, S.; Morillon, R.; Tomi, F.; Gibernau, M.; Giannettini, J.; Berti, L.; Santini, J. Triploid Citrus Genotypes Have a Better Tolerance to Natural Chilling Conditions of Photosynthetic Capacities and Specific Leaf Volatile Organic Compounds. Front. Plant Sci. 2020, 11, 330. [CrossRef]

119. Oustric, J.; Morillon, R.; Ollitrault, P.; Herbette, S.; Luro, F.; Froelicher, Y.; Tur, I.; Dambier, D.; Giannettini, J.; Berti, L.; et al. Somatic hybridization between diploid Poncirus and Citrus improves natural chilling and light stress tolerances compared with equivalent doubled-diploid genotypes. Trees 2018, 32, 883-895. [CrossRef]

120. Chen, W.; Ye, J.; Li, Y.; Zhang, Z.; Cao, Y.; Guo, W. Analysis of cold-regulated gene expression of the fingered Citron(Citrus medica L. var. sarcodactylis Swingle). Shengtai Xuebao Acta Ecol. Sin. 2013, 33, 1594-1606. [CrossRef]

121. Barkataky, S.; Ebel, R.C.; Morgan, K.T.; Dansereau, K. Water Relations of Well-watered Citrus Exposed to Cold-acclimating Temperatures. HortScience 2013, 48, 1309-1312. [CrossRef]

122. Johanson, U.; Karlsson, M.; Johansson, I.; Gustavsson, S.; Sjövall, S.; Fraysse, L.; Weig, A.R.; Kjellbom, P. The Complete Set of Genes Encoding Major Intrinsic Proteins in Arabidopsis Provides a Framework for a New Nomenclature for Major Intrinsic Proteins in Plants. Plant Physiol. 2001, 126, 1358. [CrossRef] [PubMed]

123. Maurel, C.; Boursiac, Y.; Luu, D.-T.; Santoni, V.; Shahzad, Z.; Verdoucq, L. Aquaporins in Plants. Physiol. Rev. 2015, 95, 1321-1358. [CrossRef] [PubMed]

124. Chaumont, F.; Barrieu, F.; Wojcik, E.; Chrispeels, M.J.; Jung, R. Aquaporins Constitute a Large and Highly Divergent Protein Family in Maize. Plant Physiol. 2001, 125, 1206. [CrossRef] 
125. Sakurai, J.; Ishikawa, F.; Yamaguchi, T.; Uemura, M.; Maeshima, M. Identification of 33 Rice Aquaporin Genes and Analysis of Their Expression and Function. Plant Cell Physiol. 2005, 46, 1568-1577. [CrossRef] [PubMed]

126. Reuscher, S.; Akiyama, M.; Mori, C.; Aoki, K.; Shibata, D.; Shiratake, K. Genome-Wide Identification and Expression Analysis of Aquaporins in Tomato. PLoS ONE 2013, 8, e79052. [CrossRef]

127. Gupta, A.B.; Sankararamakrishnan, R. Genome-wide analysis of major intrinsic proteins in the tree plant Populus trichocarpa: Characterization of XIP subfamily of aquaporins from evolutionary perspective. BMC Plant Biol. 2009, 9, 134. [CrossRef] [PubMed]

128. Zhang, D.Y.; Ali, Z.; Wang, C.B.; Xu, L.; Yi, J.X.; Xu, Z.L.; Liu, X.Q.; He, X.L.; Huang, Y.H.; Khan, I.A.; et al. Genome-wide sequence characterization and expression analysis of major intrinsic proteins in soybean (Glycine max L.). PLoS ONE 2013, 8 , e56312. [CrossRef] [PubMed]

129. Sreedharan, S.; Shekhawat, U.K.S.; Ganapathi, T.R. Transgenic banana plants overexpressing a native plasma membrane aquaporin MusaPIP1;2 display high tolerance levels to different abiotic stresses. Plant Biotechnol. J. 2013, 11, 942-952. [CrossRef]

130. Park, W.; Scheffler, B.E.; Bauer, P.J.; Campbell, B.T. Genome-wide identification of differentially expressed genes under water deficit stress in upland cotton (Gossypium hirsutum L.). BMC Plant Biol. 2012, 12, 90. [CrossRef] [PubMed]

131. Reddy, P.S.; Rao, T.S.R.B.; Sharma, K.K.; Vadez, V. Genome-wide identification and characterization of the aquaporin gene family in Sorghum bicolor (L.). Plant Gene 2015, 1, 18-28. [CrossRef]

132. Pedrosa, A.M.; Martins, C.D.P.S.; Gonçalves, L.P.; Costa, M.G.C. Late Embryogenesis Abundant (LEA) Constitutes a Large and Diverse Family of Proteins Involved in Development and Abiotic Stress Responses in Sweet Orange (Citrus sinensis L. Osb.). PLoS ONE 2015, 10, e0145785. [CrossRef]

133. Kriedemann, P.E.; Barrs, H.D. Chapter 5-Citrus orchards. In Woody Plant Communities; Kozlowski, T.T., Ed.; Academic Press: Cambridge, MA, USA, 1981; pp. 325-417. ISBN 978-0-12-424156-5.

134. Primo-Capella, A.; Forner-Giner, M.A. Selección de Patrones de Cítricos a Bajas Temperaturas; Instituto Valenciano de Investigaciones Agrarias: Moncada, Valencia, Spain, 2021.

135. Huang, C.; Zhou, S.; Hu, W.; Deng, X.; Wei, S.; Yang, G.; He, G. The Wheat Aquaporin Gene TaAQP7 Confers Tolerance to Cold Stress in Transgenic Tobacco. Zeitschrift Naturforsch. C 2014, 69, 142-148. [CrossRef]

136. Rahman, A.; Kawamura, Y.; Maeshima, M.; Rahman, A.; Uemura, M. Plasma Membrane Aquaporin Members PIPs Act in Concert to Regulate Cold Acclimation and Freezing Tolerance Responses in Arabidopsis thaliana. Plant Cell Physiol. 2020, 61, 787-802. [CrossRef] [PubMed]

137. Chen, T.H.H.; Murata, N. Glycinebetaine: An effective protectant against abiotic stress in plants. Trends Plant Sci. 2008, 13, 499-505. [CrossRef] [PubMed]

138. Hare, P.D.; Cress, W.A.; Van Staden, J. Dissecting the roles of osmolyte accumulation during stress. Plant. Cell Environ. 1998, 21, 535-553. [CrossRef]

139. Iba, K. Acclimative response to temperature stress in higher plants: Approaches of Gene Engineering for Temperature Tolerance. Annu. Rev. Plant Biol. 2002, 53, 225-245. [CrossRef] [PubMed]

140. Wang, W.; Vinocur, B.; Altman, A. Plant responses to drought, salinity and extreme temperatures: Towards genetic engineering for stress tolerance. Planta 2003, 218, 1-14. [CrossRef]

141. Vu, J.C.V.; Yelenosky, G. Photosnythetic responses of rough lemon and sour orange to soil flooding, chilling, and short-term temperature fluctuations during growth. Environ. Exp. Bot. 1992, 32, 471-477. [CrossRef]

142. Vu, J.C.V.; Yelenosky, G. Photosynthetic characteristics in leaves of 'Valencia' orange (Citrus sinensis (L.) Osbeck) grown under high and low temperature regimes. Environ. Exp. Bot. 1987, 27, 279-287. [CrossRef]

143. Anwar Hossain, M.; Hoque, M.A.; Burritt, D.J.; Fujita, M. Chapter 16_Proline Protects Plants Against Abiotic Oxidative Stress: Biochemical and Molecular Mechanisms; Ahmad, P.B.T.-O.D.P., Ed.; Academic Press: San Diego, CA, USA, $2014 ;$ pp. 477-522. ISBN 978-0-12-799963-0.

144. Kaur, G.; Asthir, B. Proline: A key player in plant abiotic stress tolerance. Biol. Plant. 2015, 59, 609-619. [CrossRef]

145. Kishor, P.B.K.; Sangam, S.; Amrutha, R.N.; Laxmi, P.S.; Naidu, K.R.; Rao, K.R.S.S.; Rao, S.; Reddy, K.J.; Theriappan, P.; Sreenivasulu, N. Regulation of proline biosynthesis, degradation, uptake and transport in higher plants: Its implications in plant growth and abiotic stress tolerance. Curr. Sci. 2005, 88, 424-438.

146. Szabados, L.; Savouré, A. Proline: A multifunctional amino acid. Trends Plant Sci. 2010, 15, 89-97. [CrossRef]

147. Verbruggen, N.; Hermans, C. Proline accumulation in plants: A review. Amino Acids 2008, 35, 753-759. [CrossRef]

148. Verslues, P.E.; Sharma, S. Proline Metabolism and Its Implications for Plant-Environment Interaction. Arab. Book 2010, 8, e0140. [CrossRef]

149. Verslues, P.E.; Bray, E.A. Role of abscisic acid (ABA) and Arabidopsis thaliana ABA-insensitive loci in low water potential-induced ABA and proline accumulation. J. Exp. Bot. 2006, 57, 201-212. [CrossRef]

150. Zhang, J.-R.; Tolchard, J.; Bathany, K.; Langlois D'Estaintot, B.; Chaudiere, J. Production of 3,4-cis- and 3,4-trans-Leucocyanidin and Their Distinct MS/MS Fragmentation Patterns. J. Agric. Food Chem. 2018, 66, 351-358. [CrossRef] [PubMed]

151. Cai, J.; Zeng, F.; Zheng, S.; Huang, X.; Zhang, J.; Zhang, P.; Fei, P. Preparation of Lipid-Soluble Bilberry Anthocyanins through Acylation with Cinnamic Acids and their Antioxidation Activities. J. Agric. Food Chem. 2020, 68, 7467-7473. [CrossRef] [PubMed]

152. Lo Piero, A.R. The State of the Art in Biosynthesis of Anthocyanins and Its Regulation in Pigmented Sweet Oranges [(Citrus sinensis) L. Osbeck]. J. Agric. Food Chem. 2015, 63, 4031-4041. [CrossRef] [PubMed] 
153. He, F.; Mu, L.; Yan, G.-L.; Liang, N.-N.; Pan, Q.-H.; Wang, J.; Reeves, M.J.; Duan, C.-Q. Biosynthesis of Anthocyanins and Their Regulation in Colored Grapes. Molecules 2010, 15, 9057-9091. [CrossRef]

154. Lo Piero, A.R.; Consoli, A.; Puglisi, I.; Orestano, G.; Recupero, G.R.; Petrone, G. Anthocyaninless Cultivars of Sweet Orange Lack to Express the UDP-Glucose Flavonoid 3-O-Glucosyl Transferase. J. Plant Biochem. Biotechnol. 2005, 14, 9-14. [CrossRef]

155. Lo Piero, A.R.; Puglisi, I.; Petrone, G. Gene characterization, analysis of expression and in vitro synthesis of dihydroflavonol 4-reductase from [Citrus sinensis (L.) Osbeck]. Phytochemistry 2006, 67, 684-695. [CrossRef]

156. Lo Piero, A.R.; Lo Cicero, L.; Puglisi, I. The metabolic fate of citric acid as affected by cold storage in blood oranges. J. Plant Biochem. Biotechnol. 2014, 23, 161-166. [CrossRef]

157. Peng, T.; Zhu, X.; Duan, N.; Liu, J.-H. PtrBAM1, a $\beta$-amylase-coding gene of Poncirus trifoliata, is a CBF regulon member with function in cold tolerance by modulating soluble sugar levels. Plant. Cell Environ. 2014, 37, 2754-2767. [CrossRef]

158. Rai, A.N.; Penna, S. Molecular evolution of plant P5CS gene involved in proline biosynthesis. Mol. Biol. Rep. 2013, 40, 6429-6435. [CrossRef]

159. Sicilia, A.; Scialò, E.; Puglisi, I.; Lo Piero, A.R. Anthocyanin Biosynthesis and DNA Methylation Dynamics in Sweet Orange Fruit [Citrus sinensis L. (Osbeck)] under Cold Stress. J. Agric. Food Chem. 2020, 68, 7024-7031. [CrossRef]

160. Mohammadrezakhani, S.; Hajilou, J.; Rezanejad, F.; Zaare-Nahandi, F. Assessment of exogenous application of proline on antioxidant compounds in three Citrus species under low temperature stress. J. Plant Interact. 2019, 14, 347-358. [CrossRef]

161. Mohammadian, M.A.; Mobrami, Z.; Sajedi, R.H. Bioactive compounds and antioxidant capacities in the flavedo tissue of two citrus cultivars under low temperature. Braz. J. Plant Physiol. 2011, 23, 203-208. [CrossRef]

162. Lo Piero, A.R.; Puglisi, I.; Petrone, G. Gene Isolation, Analysis of Expression, and in Vitro Synthesis of Glutathione S-Transferase from Orange Fruit [Citrus sinensis L. (Osbeck)]. J. Agric. Food Chem. 2006, 54, 9227-9233. [CrossRef]

163. Sanchez-Ballesta, M.T.; Lafuente, M.T.; Zacarias, L.; Granell, A. Involvement of phenylalanine ammonia-lyase in the response of Fortune mandarin fruits to cold temperature. Physiol. Plant. 2000, 108, 382-389. [CrossRef]

164. Perotti, V.E.; Moreno, A.S.; Trípodi, K.E.J.; Meier, G.; Bello, F.; Cocco, M.; Vázquez, D.; Anderson, C.; Podestá, F.E. Proteomic and metabolomic profiling of Valencia orange fruit after natural frost exposure. Physiol. Plant. 2015, 153, 337-354. [CrossRef]

165. Chater, C.; Kamisugi, Y.; Movahedi, M.; Fleming, A.; Cuming, A.C.; Gray, J.E.; Beerling, D.J. Regulatory mechanism controlling stomatal behavior conserved across 400 million years of land plant evolution. Curr. Biol. 2011, 21, 1025-1029. [CrossRef]

166. Finkelstein, R. Abscisic Acid synthesis and response. Arab. B. 2013, 11, e0166. [CrossRef] [PubMed]

167. Nakashima, K.; Ito, Y.; Yamaguchi-Shinozaki, K. Transcriptional Regulatory Networks in Response to Abiotic Stresses in Arabidopsis and Grasses. Plant Physiol. 2009, 149, 88. [CrossRef] [PubMed]

168. Rook, F.; Hadingham, S.A.; Li, Y.; Bevan, M.W. Sugar and ABA response pathways and the control of gene expression. Plant. Cell Environ. 2006, 29, 426-434. [CrossRef] [PubMed]

169. Bray, E.A. Plant responses to water deficit. Trends Plant Sci. 1997, 2, 48-54. [CrossRef]

170. Finkelstein, R.R.; Gibson, S.I. ABA and sugar interactions regulating development: Cross-talk or voices in a crowd? Curr. Opin. Plant Biol. 2002, 5, 26-32. [CrossRef]

171. Thomashow, M.F. Plant Cold Acclimation: Freezing Tolerance Genes and Regulatory Mechanisms. Annu. Rev. Plant Physiol. Plant Mol. Biol. 1999, 50, 571-599. [CrossRef]

172. Vishwakarma, K.; Upadhyay, N.; Kumar, N.; Yadav, G.; Singh, J.; Mishra, R.K.; Kumar, V.; Verma, R.; Upadhyay, R.G.; Pandey, M.; et al. Abscisic Acid Signaling and Abiotic Stress Tolerance in Plants: A Review on Current Knowledge and Future Prospects. Front. Plant Sci. 2017, 8, 161. [CrossRef]

173. Boudsocq, M.; Droillard, M.-J.; Barbier-Brygoo, H.; Laurière, C. Different phosphorylation mechanisms are involved in the activation of sucrose non-fermenting 1 related protein kinases 2 by osmotic stresses and abscisic acid. Plant Mol. Biol. 2007, 63, 491-503. [CrossRef]

174. Ding, Y.; Jia, Y.; Shi, Y.; Zhang, X.; Song, C.; Gong, Z.; Yang, S. OST1-mediated BTF3L phosphorylation positively regulates CBFs during plant cold responses. EMBO J. 2018, 37, e98228. [CrossRef]

175. Guo, Y.; Halfter, U.; Ishitani, M.; Zhu, J.K. Molecular characterization of functional domains in the protein kinase SOS2 that is required for plant salt tolerance. Plant Cell 2001, 13, 1383-1400. [CrossRef] [PubMed]

176. Ho, C.-H.; Lin, S.-H.; Hu, H.-C.; Tsay, Y.-F. CHL1 Functions as a Nitrate Sensor in Plants. Cell 2009, 138, 1184-1194. [CrossRef] [PubMed]

177. Lin, H.; Yang, Y.; Quan, R.; Mendoza, I.; Wu, Y.; Du, W.; Zhao, S.; Schumaker, K.S.; Pardo, J.M.; Guo, Y. Phosphorylation of SOS3-Like Calcium Binding Protein8 by SOS2 Protein Kinase Stabilizes Their Protein Complex and Regulates Salt Tolerance in Arabidopsis. Plant Cell 2009, 21, 1607. [CrossRef] [PubMed]

178. Ma, Q.-J.; Sun, M.-H.; Lu, J.; Kang, H.; You, C.-X.; Hao, Y.-J. An apple sucrose transporter MdSUT2.2 is a phosphorylation target for protein kinase MdCIPK22 in response to drought. Plant Biotechnol. J. 2019, 17, 625-637. [CrossRef]

179. Shinozawa, A.; Otake, R.; Takezawa, D.; Umezawa, T.; Komatsu, K.; Tanaka, K.; Amagai, A.; Ishikawa, S.; Hara, Y.; Kamisugi, Y.; et al. SnRK2 protein kinases represent an ancient system in plants for adaptation to a terrestrial environment. Commun. Biol. 2019, 2, 30. [CrossRef]

180. Stevenson, S.R.; Kamisugi, Y.; Trinh, C.H.; Schmutz, J.; Jenkins, J.W.; Grimwood, J.; Muchero, W.; Tuskan, G.A.; Rensing, S.A.; Lang, D.; et al. Genetic analysis of Physcomitrella patens identifies ABSCISIC ACID NON-RESPONSIVE (ANR), a regulator of ABA responses unique to basal land plants and required for desiccation tolerance. Plant Cell 2016, 28, 1310. [CrossRef] 
181. Huang, Y.; Li, C.Y.; Qi, Y.; Park, S.; Gibson, S.I. SIS8, a putative mitogen-activated protein kinase kinase kinase, regulates sugar-resistant seedling development in Arabidopsis. Plant J. 2014, 77, 577-588. [CrossRef]

182. Hwang, J.-U.; Yim, S.; Do, T.H.T.; Kang, J.; Lee, Y. Arabidopsis thaliana Raf22 protein kinase maintains growth capacity during postgerminative growth arrest under stress. Plant Cell Environ. 2018, 41, 1565-1578. [CrossRef]

183. Lee, S.; Lee, M.H.; Kim, J.-I.; Kim, S.Y. Arabidopsis Putative MAP Kinase Kinase Kinases Raf10 and Raf11 are Positive Regulators of Seed Dormancy and ABA Response. Plant Cell Physiol. 2015, 56, 84-97. [CrossRef]

184. Nguyen, Q.T.C.; Lee, S.-J.; Choi, S.-W.; Na, Y.-J.; Song, M.-R.; Hoang, Q.T.N.; Sim, S.Y.; Kim, M.-S.; Kim, J.-I.; Soh, M.-S.; et al. Arabidopsis Raf-Like Kinase Raf10 Is a Regulatory Component of Core ABA Signaling. Mol. Cells 2019, 42, 646-660. [CrossRef]

185. Saruhashi, M.; Kumar Ghosh, T.; Arai, K.; Ishizaki, Y.; Hagiwara, K.; Komatsu, K.; Shiwa, Y.; Izumikawa, K.; Yoshikawa, H.; Umezawa, T.; et al. Plant Raf-like kinase integrates abscisic acid and hyperosmotic stress signaling upstream of SNF1-related protein kinase2. Proc. Natl. Acad. Sci. USA 2015, 112, E6388. [CrossRef]

186. Baron, K.N.; Schroeder, D.F.; Stasolla, C. Transcriptional response of abscisic acid (ABA) metabolism and transport to cold and heat stress applied at the reproductive stage of development in Arabidopsis thaliana. Plant Sci. 2012, 188-189, 48-59. [CrossRef]

187. Maruyama, K.; Urano, K.; Yoshiwara, K.; Morishita, Y.; Sakurai, N.; Suzuki, H.; Kojima, M.; Sakakibara, H.; Shibata, D.; Saito, K.; et al. Integrated Analysis of the Effects of Cold and Dehydration on Rice Metabolites, Phytohormones, and Gene Transcripts. Plant Physiol. 2014, 164, 1759. [CrossRef]

188. Chen, C.-C.; Liang, C.-S.; Kao, A.-L.; Yang, C.-C. HHP1, a novel signalling component in the cross-talk between the cold and osmotic signalling pathways in Arabidopsis. J. Exp. Bot. 2010, 61, 3305-3320. [CrossRef]

189. Nakashima, K.; Yamaguchi-Shinozaki, K.; Shinozaki, K. The transcriptional regulatory network in the drought response and its crosstalk in abiotic stress responses including drought, cold, and heat. Front. Plant Sci. 2014, 5, 170. [CrossRef] [PubMed]

190. Shinozaki, K.; Yamaguchi-Shinozaki, K. Molecular responses to dehydration and low temperature: Differences and cross-talk between two stress signaling pathways. Curr. Opin. Plant Biol. 2000, 3, 217-223. [CrossRef]

191. Du, H.; Liu, H.; Xiong, L. Endogenous auxin and jasmonic acid levels are differentially modulated by abiotic stresses in rice. Front. Plant Sci. 2013, 4, 397. [CrossRef]

192. Hu, Y.; Jiang, L.; Wang, F.; Yu, D. Jasmonate regulates the inducer of cbf expression-C-repeat binding factor/DRE binding factor1 cascade and freezing tolerance in Arabidopsis. Plant Cell 2013, 25, 2907-2924. [CrossRef]

193. Kosová, K.; Prášil, I.T.; Vítámvás, P.; Dobrev, P.; Motyka, V.; Floková, K.; Novák, O.; Turečková, V.; Rolčik, J.; Pešek, B.; et al. Complex phytohormone responses during the cold acclimation of two wheat cultivars differing in cold tolerance, winter Samanta and spring Sandra. J. Plant Physiol. 2012, 169, 567-576. [CrossRef] [PubMed]

194. Xian, L.; Sun, P.; Hu, S.; Wu, J.; Liu, J.-H. Molecular cloning and characterization of CrNCED1, a gene encoding 9-cisepoxycarotenoid dioxygenase in Citrus reshni, with functions in tolerance to multiple abiotic stresses. Planta 2014, $239,61-77$. [CrossRef]

195. He, L.G.; Jiang, Y.C.; Wang, H.L.; Xu, M.; Sun, Z.H. Expression and regulation of a cold-responsive gene, CsCBF in Citrus sinensis (L.) Osbeck under low temperature, high salinity and abscisic acid. Acta Hortic. 2016, 1135, 33-46. [CrossRef]

196. Melgoza, F.J.; Kusakabe, A.; Nelson, S.D.; Melgar, J.C. Exogenous Applications of Abscisic Acid Increase Freeze Tolerance in Citrus Trees. Int. J. Fruit Sci. 2014, 14, 376-387. [CrossRef]

197. Hua, Y.; Huang, L.; Raol, L.-Q.; Long, G.-Y.; Shi, G.-R.; Peng, G.-P. Effects of exogenous ABA on antioxidant enzymes in detached citrus leaves treated by rapid freezing. Afr. J. Biotechnol. 2013, 10, 9779-9785. [CrossRef] 